Cochrane Database of Systematic Reviews

\title{
Enzyme replacement therapy with idursulfase for mucopolysaccharidosis type II (Hunter syndrome) (Review)
}

da Silva EMK, Strufaldi MWL, Andriolo RB, Silva LA

da Silva EMK, Strufaldi MWL, Andriolo RB, Silva LA.

Enzyme replacement therapy with idursulfase for mucopolysaccharidosis type II (Hunter syndrome).

Cochrane Database of Systematic Reviews 2016, Issue 2. Art. No.: CD008185.

DOI: 10.1002/14651858.CD008185.pub4.

www.cochranelibrary.com 
TABLE OF CONTENTS

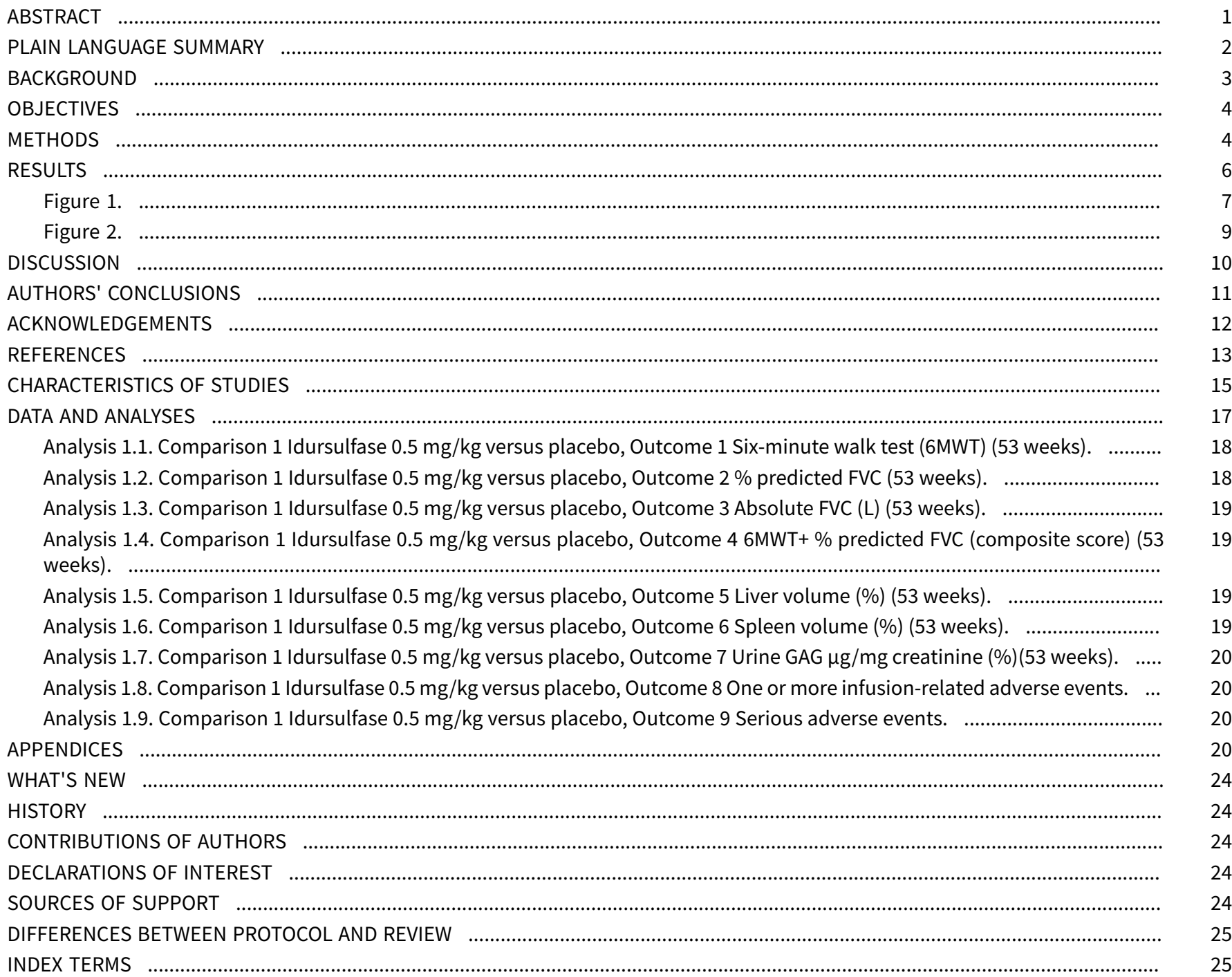


[Intervention Review]

\section{Enzyme replacement therapy with idursulfase for mucopolysaccharidosis type II (Hunter syndrome)}

Edina MK da Silva1 ${ }^{1}$, Maria Wany Louzada Strufaldi², Regis B Andriolo ${ }^{3}$, Laercio A Silva4

1Emergency Medicine and Evidence Based Medicine, Universidade Federal de São Paulo, São Paulo, Brazil. 2Universidade Federal de São Paulo, São Paulo, Brazil. ${ }^{3}$ Department of Public Health, Universidade do Estado do Pará, Belém, Brazil. ${ }^{4}$ Department of Urology, Universidade Federal de São Paulo, São Paulo, Brazil

Contact: Edina MK da Silva, Emergency Medicine and Evidence Based Medicine, Universidade Federal de São Paulo, Rua Borges Lagoa 564 cj 64, Vl. Clementino, São Paulo, São Paulo, 04038-000, Brazil. edinaksilva@terra.com.br.

Editorial group: Cochrane Cystic Fibrosis and Genetic Disorders Group.

Publication status and date: New search for studies and content updated (no change to conclusions), published in Issue 2, 2016.

Citation: da Silva EMK, Strufaldi MWL, Andriolo RB, Silva LA. Enzyme replacement therapy with idursulfase for mucopolysaccharidosis type II (Hunter syndrome). Cochrane Database of Systematic Reviews 2016, Issue 2. Art. No.: CD008185. DOI: 10.1002/14651858.CD008185.pub4.

Copyright ( 2016 The Cochrane Collaboration. Published by John Wiley \& Sons, Ltd.

\section{A B S T R A C T}

\section{Background}

Mucopolysaccharidosis II, also known as Hunter syndrome, is a rare, X-linked disease caused by a deficiency of the lysosomal enzyme iduronate-2-sulfatase, which catalyses a step in the catabolism of glycosaminoglycans. The glycosaminoglycans accumulate within tissues affecting multiple organs and physiologic systems. The clinical manifestations include neurologic involvement, severe airways obstruction, skeletal deformities and cardiomyopathy. The disease has a variable age of onset and variable rate of progression. In those with severe disease, death usually occurs in the second decade of life, whereas those individuals with less severe disease may survive into adulthood. Enzyme replacement therapy with intravenous infusions of idursulfase has emerged as a new treatment for mucopolysaccharidosis type II. This is an update of a previously published version of this review.

\section{Objectives}

To evaluate the effectiveness and safety of enzyme replacement therapy with idursulfase compared to other interventions, placebo or no intervention, for treating mucopolysaccharidosis type II.

\section{Search methods}

We searched the Cochrane Cystic Fibrosis and Genetic Disorders Group's Trials Register (date of last search 23 November 2015).

We also searched Embase, PubMed and the Literature Latino-Americana e do Caribe em Ciências da Saúde (LILACS) (date of last search 28 November 2015).

\section{Selection criteria}

Randomised and quasi-randomised controlled trials of enzyme replacement therapy with idursulfase compared to no intervention, placebo or other options (e.g. behavioral strategies, transplantation).

\section{Data collection and analysis}

Two authors independently screened the trials identified, appraised quality of papers and extracted data. 


\section{Main results}

One study (96 male participants) met the inclusion criteria, although the primary outcome of this review - $\mathrm{z}$ score for height and weight, was not assessed in the study. This trial was considered to be of overall good quality. Following 53 weeks of treatment, participants in the weekly idursulfase $0.5 \mathrm{mg} / \mathrm{kg}$ group demonstrated a significant improvement rate compared with placebo for the primary outcome: distance walked in six minutes on the basis of the sum of ranks of change from baseline, mean difference 37.00 ( $95 \%$ confidence interval 6.52 to 67.48 ). The every-other-week idursulfase $0.5 \mathrm{mg} / \mathrm{kg}$ group also showed an improvement, which was not significant compared with placebo, mean difference 23.00 (95\% confidence interval -4.49 to 50.49). After 53 weeks, there was no statistical significance difference in per cent predicted forced vital capacity between the three groups and absolute forced vital capacity was significantly increased from baseline in the weekly dosing group compared to placebo, mean difference 0.16 ( $95 \%$ confidence interval $\mathrm{Cl} 0.05$ to 0.27 ). No difference was observed between the every-other-week idursulfase $0.5 \mathrm{mg} / \mathrm{kg}$ group and placebo.

In addition, liver and spleen volumes and urine glycosaminoglycan excretion were significantly reduced from baseline by both idursulfase dosing regimens. Idursulfase was generally well tolerated, but infusion reactions did occur. Idursulfase antibodies were detected in $31.7 \%$ of participants at the end of the study and they were related to a smaller reduction in urine glycosaminoglycan levels.

\section{Authors' conclusions}

The current evidence is limited. While the randomised clinical trial identified was considered to be of good quality, it failed to describe important outcomes. It has been demonstrated that enzyme replacement therapy with idursulfase is effective in relation to functional capacity (distance walked in six minutes and forced vital capacity), liver and spleen volumes and urine glycosaminoglycan excretion in people with mucopolysaccharidosis type II compared with placebo. There is no available evidence in the included study and in the literature on outcomes such as improvement in growth, sleep apnoea, cardiac function, quality of life and mortality. More studies are needed to obtain more information on the long-term effectiveness and safety of enzyme replacement therapy.

\section{PLAIN LANGUAGE SUMMARY}

\section{Enzyme replacement therapy with idursulfase for mucopolysaccharidosis type II (Hunter syndrome)}

\section{Review question}

We reviewed the evidence about the effect and safety of enzyme replacement therapy with idursulfase compared to other interventions, placebo ('dummy treatment') or no intervention, for treating people with mucopolysaccharidosis type II. This is an update of a previously published version of this review.

\section{Background}

Hunter syndrome or mucopolysaccharidosis II is a rare genetic disease that occurs when an enzyme that the body needs is either missing or malfunctioning. The body doesn't have adequate supplies of this enzyme to break down certain complex molecules, so these molecules build up in harmful amounts in certain cells and tissues. The build-up that occurs in Hunter syndrome eventually causes permanent, progressive damage affecting appearance, mental development, organ function and physical abilities. Hunter syndrome appears in children as young as the age of two years and it nearly always occurs in males. In the past, treatment of Hunter syndrome has been limited to the relief of symptoms and complications. Enzyme replacement therapy with idursulfase aims to replace iduronate-2-sulfatase, the enzyme that is deficient or absent in people with Hunter syndrome. However, given its high cost it is essential to assess how effective and safe this treatment is.

\section{Search date}

The evidence is current to: 23 November 2015.

\section{Study characteristics}

The review included one study with 96 males with Hunter syndrome aged between 4.9 and 30.9 years of age. The trial compared idursulfase $0.5 \mathrm{mg} / \mathrm{kg}$ given either weekly or every-other week, or weekly infusions of placebo (a substance which contains no medication) and people were selected for one treatment or the other randomly. The study lasted 53 weeks.

\section{Key results}

Current evidence is limited given there was only one randomised clinical trial found in the medical literature. As compared with placebo, enzyme replacement therapy with idursulfase in people with Hunter syndrome, led to some improvement in the individuals' ability to walk and a reduction in the excretion of abnormal mucopolysaccharides in the urine. To date there is no evidence available in the literature showing that treatment reduces complications of the disease related to quality of life and mortality.

\section{Quality of the evidence}

This trial was considered to be of overall good quality. 


\section{B A C K G R O U N D}

\section{Description of the condition}

Mucopolysaccharidosis II (MPS II or Hunter syndrome) belongs to a group of inherited diseases of glycosaminoglycan (GAG) catabolism called mucopolysaccharidoses. The GAGs are oligosaccharide components of the proteoglycans, macromolecules responsible for the integrity and function of connective tissue. Mucopolysaccharidoses are caused by a lysosomal enzyme deficiency for the stepwise degradation of the GAGs. All of the mucopolysaccharidoses are of recessive autosome inheritance, except MPS II, which is an X-linked recessive disease. The syndrome was described by Charles Hunter in 1917 and is the result of a deficiency of iduronate-2-sulfatase (I2S), with consequent increase of the urinary concentration of the GAGs dermatan sulphate and heparan sulphate. The clinical phenotype of MPS II is characterised by progressive pathological lysosomal storage of GAGs in nearly all cell types, tissues and organs. The iduronate 2-sulfatase gene is located on chromosome Xq28, and more than 350 mutations have been identified to date, including different deletions, splice-site and point mutations. This genetic heterogeneity may explain the high degree of clinical heterogeneity in MPS II (Martin 2008; Wraith 2008a).

This is a rare disease with an estimated incidence of approximately 1 in 162,000 live births. Although males are predominantly affected, a small number of affected females have been described (Meikle 1999; Tuschl 2005). This is a variable, progressive, multisystem disease and should be regarded as a continuum between two extremes (severe and attenuated). Two-thirds of individuals present central nervous system (CNS) involvement, representing the more severe form, with clinical features appearing between two and four years of age. In these cases, the progressive neurologic involvement is prominent and leads to severe mental impairment; death usually occurs in the first or second decade of life, usually because of obstructive airway disease or cardiac failure (or both) associated with loss of neurologic function. At the opposite end of the spectrum, clinical signs and symptoms have a slightly later onset and the neurologic dysfunction may be minimal, but with obvious somatic involvement, and longer survival (Wraith 2008a). Data from the 'Hunter Outcome Survey' (HOS), the only largescale, multinational observational study of people with MPS II, showed that median age at death was significantly lower in those with cognitive involvement compared with those without cognitive involvement (11.7 versus 14.1 years; $P=0.024$ ) (Jones 2008).

The most common clinical signs and symptoms include dysostosis multiplex with decreased range of joint motion, coarse facial features, enlarged tongue, hearing loss, abnormal dentition, upper airway obstruction with or without sleep apnoea, restrictive lung disease, hepatosplenomegaly, cardiomyopathy, skeletal deformities, and severe short stature (Young 1983).

The development of children with MPS II seems normal in the first months of life, but the outcome is highly changeable. Even in individuals with attenuated disease, cranial magnetic resonance imaging (MRI) scans are often grossly abnormal, with extensive white matter changes as well as dilated perivascular spaces, despite apparently normal intellectual skills. Individuals with more severe MPS II also appear normal at birth, and early development may be normal. Some individuals fail hearing screening tests in the first year, and speech delay is not unusual in those more severely affected. By 18 to 24 months developmental delay is usually apparent. Most individuals make very slow progress after this stage, with a developmental plateau beginning between three and five years of age. Unlike children with severe MPS I, who are usually placid, more severely affected children with MPS II can be hyperactive and aggressive. One of the most important limitations beside the neurologic involvement in individuals suffering from MPS II, is the impact that the progressive physical abnormalities have on their quality of life. Due to a combination of the bone disease, decreased respiratory capacity and impaired cardiac function, they suffer from chronic, severely diminished endurance. With the disease progression their ability to walk even short distances may be lost and eventually many people become wheelchair-bound. By the time of death in their second decade, most individuals with CNS involvement show severe learning difficulties and are dependant on care providers for all their needs (Wraith 2008a).

The measurement of urinary GAGs (heparan and dermatan sulphate) is the usual first screening test for MPS II. As in almost all cases of MPS, the total urinary GAG level is increased. However, this is not diagnostic of MPS II, so additional tests must be performed. Futhermore, a negative urine GAG test does not necessarily rule out a diagnosis of MPS II, because false-negative results can occur as a result of a lack of sensitivity of the testing method (de Jong 1992). Definitive diagnosis is established by enzyme assay in leukocytes, fibroblasts or plasma, using substrates specific for I2S. Absent or low I2S activity in males is diagnostic of MPS II, provided that multiple sulphatase deficiency is excluded by finding normal activity of another sulphatase. Absolute enzyme activity cannot be used to predict the severity of the phenotype. Mutation analysis may be used to confirm Hunter syndrome in males. However, it is difficult to establish a genotype-phenotype correlation to provide an indication of the likely prognosis, this is because individuals carrying the same alterations may present different phenotypes, suggesting that others factors may modulate the clinical phenotype (Kresse 1982;Martin 2008; Neufeld 2001).

As the definition of effective treatment for MPS $\|$ is "an improvement in or a prevention of progression of disease activity as indicated by a stabilisation in clinical condition associated with an improvement in the abnormalities present at baseline" (Vellodi 2007), the primary endpoints for the evaluation of interventions for the treatment of this condition should reflect improvement in important signs and symptoms observed in the disease, such as a change in the speed of growth and in the impairment of cardiac and respiratory system.

The usual management of MPS II has been palliative and focused on the treatment of signs and symptoms. Care for the person with MPS II involves a multidisciplinary approach and includes paediatricians, neurologists, orthopedists, otolaryngologists, ophthalmologists, and occupational and physical therapists, as well as geneticists and counsellors (National Horizon Scanning Centre 2005). Hemapoietic stem cell transplantation (HSCT) by bone marrow transplantation, human amnion membrane implantation, fibroblast transplantation, serum or plasma infusion has been suggested as a means of providing donor cells capable of expressing $12 \mathrm{~S}$, but the results are disappointing and longterm outcomes are limited, therefore, HSCT is not currently recommended for individuals with MPS II (Martin 2008). 


\section{Description of the intervention}

Recently idursulfase (Elaprase ${ }^{\circledast}$, Shire Human Genetic Therapies, Inc, Cambridge, MA), a recombinant human I2S produced in a human cell line, was approved in the United States of America and the European Union for the treatment of MPS II.

\section{How the intervention might work}

The rationale for therapy is that exogenous $12 \mathrm{~S}$ would replace the I2S that is deficient in people with MPS II and either stop or reverse disease progression. Idursulfase is produced in a continuous human cell line and is a purified form of the natural lysosomal enzyme 12S. Mannose-6-phosphate (M6P) residues on the oligosaccharide chains of the glycoprotein enzyme and allows specific binding of idursulfase to M6P receptors on the cell surface, leading to cellular internalisation and targeting of the enzyme to lysosomes, and subsequent catabolism of accumulated GAGs (Wraith 2008b).

\section{Why it is important to do this review}

There is no definitive treatment for people diagnosed with MPS II. The appearance of a promising therapeutic strategy, idursulfase, makes it necessary to map the knowledge in this area based on the rigor inherent to systematic reviews by considering relevant aspects of the effectiveness and safety of this therapeutic strategy for relevant clinical issues.

The current publication is a minor update of a Cochrane review first published in 2011 and again in 2014 (da Silva 2011; da Silva 2014).

\section{O B JE C T IVES}

To evaluate the effectiveness and safety of enzyme replacement therapy with idursulfase compared to other interventions, placebo or no intervention, for treating mucopolysaccharidosis type II.

\section{METHOD S}

\section{Criteria for considering studies for this review Types of studies}

Randomised and quasi-randomised controlled clinical trials of parallel or cross-over design.

\section{Types of participants}

Individuals with MPS II (Hunter syndrome) of any age and any degree of disease severity. Diagnosis should be established by enzyme assay in leukocytes, fibroblasts or plasma, using substrates specific for I2S.

\section{Types of interventions}

Enzyme replacement therapy with idursulfase in any amount given for a period of at least one month compared to:

- no intervention;

- placebo;

- other options (e.g. behavioral strategies, transplantation).

\section{Types of outcome measures}

Following further advice from the Cochrane Cystic Fibrosis and Genetic Disorders Editorial Team, we have made post hoc changes to the outcomes. Previously listed as primary outcomes - 'left ventricular mass index' and 'overnight apnoea-hypopnoea index (AHI)' have been re-allocated to secondary outcomes. The sixminute walk test (6MWT) has been re-allocated from secondary outcomes to primary outcomes. Given that MPS II is a disease with multiorgan and multisystem involvement, a variable age of onset and a variable rate of progression, we found the choice of representative outcomes a challenge. Since appropriate growth is a key clinical feature in children and this is altered in all forms of MPS II, we selected $\mathrm{z}$ score of weight and height as the primary outcome (Martin 2008; Wraith 2008a). As studies may include adults, the functional capacity test 6MWT was also selected as a primary outcome because this standardized test is the most often used to measure functional capacity (ATS 2002). Outcomes that represent changes in other organs and systems are listed as secondary.

\section{Primary outcomes}
1. Z scores for
a. height
b. weight

2. Six-minute walk test (6MWT)

\section{Secondary outcomes}

1. Lung function

a. forced expiratory volume at one second $\left(\mathrm{FEV}_{1}\right)$

b. forced vital capacity (FVC)

c. any other measure of lung function (e.g. Rint)

2. Overnight apnoea-hypopnoea index (AHI)

3. Left ventricular mass index

4. Joint mobility score (using a validated scoring system)

5. Liver and spleen volume (measured by abdominal MRI)

6. Quality of life (using a validated scoring system)

7. Pain (using a validated scoring system e.g. visual analogue scales (VAS))

8. Rate of hospitalizations

9. Resources required for home care support

10. Changes in glycosaminoglycans (GAGs) urinary excretion

11.Developmental score

12.Audiologic assessment (e.g. pure tone audiogram, distortion product otoacoustic emission (DPOE), evoked responses)

13.Age at death

14.Adverse effects $(\mathrm{AE})$ and toxicity of treatment

\section{Search methods for identification of studies}

\section{Electronic searches}

There was no language restriction and the trials were identified from the sources listed below.

We identified relevant trials from the Cochrane Cystic Fibrosis and Genetic Disorders Group's Inborn Errors of Metabolism Trials Register using the term: mucopolysaccharidosis.

This register was compiled from electronic searches of the Cochrane Central Register of Controlled Trials (CENTRAL) (updated each new issue of The Cochrane Library), weekly searches of MEDLINE and the prospective handsearching of the Journal of Inherited Metabolic Disease. Unpublished work were identified by 
searching through the abstract books of the Society for the Study of Inborn Errors of Metabolism conference and the SHS Inborn Error Review Series. For full details of all searching activities for the register, please see the relevant section of the Cystic Fibrosis and Genetic Disorders Group Module.

We also searched Embase (1980 to 23 November 2015), PubMed (1980 to 23 November 2015) and the Literature Latino-Americana e do Caribe em Ciências da Saúde - LILACS (1982 to 23 November 2015). The search strategy was composed of the terms 'enzyme replacement therapy' and 'Mucopolysaccharidosis II'. We searched with both, subject headings and free text words (see Appendix 1; Appendix 2; Appendix 3).

Date of most recent search of the Cochrane Cystic Fibrosis and Genetic Disorders Group's Inborn Errors of Metabolism Trials Register: 23 November 2015.

\section{Searching other resources}

Reference lists of any identified relevant studies were scrutinized for additional citations.

\section{Data collection and analysis}

\section{Selection of studies}

Two authors (EMKS and LAS) independently screened the studies identified by the literature search. When disagreements occurred they consulted a third author (RBA) and did not include data until they reached a consensus.

\section{Data extraction and management}

Two authors (EMKS and LAS) extracted data independently; they resolved discrepancies in the results by discussion. The authors used a standard form to extract the following information: characteristics of the study (design, method of randomisation); participants; interventions; and outcomes (types of outcome measures, timing of outcomes, adverse events).

The authors planned to report outcomes at up to and including three months, over three months and up to six months, over six months and up to twelve months and then annually thereafter. They also planned to consider additional follow-up data recorded at more than 12 months. Given only one trial is currently included they have reported these data at 53 weeks, as within the trial.

The included trial reported standard errors (SE) ; the authors converted these to standard deviations (SD) $(S D=S E x$ square root of $n)$.

\section{Assessment of risk of bias in included studies}

In order to assess the risk of bias, two review authors independently assessed the quality of the studies included in the review according to the criteria described in the Cochrane Handbook For Systemtic Review of Interventions (Higgins 2011a).

They assessed the following domains as having either a low, unclear or high risk of bias.

1. Was the sequence generation adequate?

2. Was allocation adequately concealed?

3. Was knowledge of the allocated interventions adequately prevented during the study?
4. Were incomplete outcome data adequately addressed?

5. Are reports of the study free of suggestion of selective outcome reporting?

6. Was the study apparently free of other problems that could put it at a high risk of bias?

The authors reported these assessments for each individual study in the 'Risk of bias' table in the section 'Characteristics of included studies'.

If necessary, for future updates, they plan to contact the study author(s) to seek clarification in case of uncertainty over data.

\section{Measures of treatment effect}

For dichotomous variables, the authors calculated the risk ratio (RR) and 95\% confidence intervals (Cls). For continuous outcomes, they calculated the mean difference (MD) and 95\% Cls. In this review the authors did not identify studies in which the authors did not publish or make available the necessary information to be included in the review. For further studies identified in subsequent updates of this review, the authors will insert any data from primary studies which are not parametric (e.g. effects reported as medians, quartiles, etc) or without sufficient statistical information (e.g., SDs, number of participants, etc) into an 'Additional table'.

\section{Unit of analysis issues}

The unit of analysis is based on the individual participant (unit to be randomised for interventions to be compared), i.e. the number of observations in the analysis should match the number of individuals randomised. The authors did not identify trials with a cross-over design, if in subsequent updates they include such trials, they will use only first-arm data (before participants have crossed over the treatments) (Elbourne 2002).

\section{Dealing with missing data}

Irrespective of the type of data, the authors reported dropout rates in the Characteristics of included studies table and they used intention-to-treat analysis (Higgins 2011b).

\section{Assessment of heterogeneity}

As the authors only included one study they did not evaluate heterogeneity. In future updates, they will qualify inconsistency among the pooled estimates using the $\mathrm{I}^{2}=[(\mathrm{Q}-\mathrm{df}) / \mathrm{Q}] \times 100 \%$ test, where $\mathrm{Q}$ is the chi-squared statistic and $\mathrm{df}$ its degrees of freedom. This illustrates the percentage of the variability in effect estimates resulting from heterogeneity rather than sampling error (Higgins 2003; Higgins 2011a). The thresholds for the interpretation of $\mathrm{I}^{2}$ will be as follows: $0 \%$ to $25 \%$ low heterogeneity; $25 \%$ to $75 \%$ moderate heterogeneity; and more than $75 \%$ significant heterogeneity (Higgins 2003).

\section{Assessment of reporting biases}

In future updates of this review, if a sufficient number of studies (at least 10) are included, the authors will assess publication bias by drawing a funnel plot (trial effect versus trial size). 


\section{Data synthesis}

\section{Qualitative information}

The authors synthesized qualitative information relative to methods, risk of bias, description of participants and outcome measures and inserted this information in the table of Characteristics of included studies.

\section{Quantitative information}

For dichotomous variables, the authors calculated the RR and 95\% $\mathrm{Cls}$. For continuous variables, we calculated the MD and $95 \% \mathrm{Cls}$.

In subsequent updates of this review, if continuous data relate to the same outcome, but are measured with different instruments (different and not interchangeable units of measure), the authors will pool these data using the standardised mean difference (SMD). For all statistical methods when pooling data, they will report the $95 \% \mathrm{Cls}$. If they do not identify any significant heterogeneity, they will compute pooled estimates of the treatment effect for each outcome under a fixed-effect model. Otherwise, if they identify significant heterogeneity, they will perform a randomeffects analysis.

\section{Subgroup analysis and investigation of heterogeneity}

In subsequent updates of this review, If the authors find significant heterogeneity, they will investigate the possible causes of this further by exploring the impact of the condition of the individuals (i.e. severity of disease, duration of treatment). If they find sources of heterogeneity and if there are sufficient data, they will conduct meta-analyses by subgroups (by types of dosage and duration of intervention, disease stage, age at onset).

\section{Sensitivity analysis}

As only one study was included in this review, the authors did not perform any sensitivity analyses, but will do so if there are an adequate number of studies included in future updates. If, in the future, they are able to perform a sensitivity analysis, they will do so with an aim to explore possible causes of heterogeneity and the robustness of the results.

We will include the following factors in any sensitivity analysis, separating studies according to:

1. allocation concealment quality (low, unclear or high risk);

2. blinding of participants, caregiver and outcome assessment (low, unclear or high risk, or not performed);

3. rates of withdrawal for each outcome;

4. length of follow-up;

5. age of participants;

6. disease severity.

\section{RES ULTS}

\section{Description of studies}

\section{Results of the search}

There were 202 records identified by the searches: MEDLINE (PubMed): 103 references to studies; Cochrane Cystic Fibrosis and Genetic Disorders Group's Trials Register: 43 references; EMBASE: 60 references; LILACS: 3 references. The authors also scrutinised the bibliographical references of these papers for further potentially eligible studies and found no additional references. After closer examination of the titles and abstracts of these references, all but eight studies were subsequently excluded from further analysis. If possible, full text copies of these remaining studies were obtained and were then subjected to further assessment. Following the verification of the whole studies, only one of them fulfilled all the inclusion criteria of this review (Muenzer 2006) and six studies were excluded (Muenzer 2007; Gutiérrez-Solana 2007; Tylki-Szymanska 2008; Sohn 2013) (Figure 1). An additional study is ongoing (NCT02055118). 
Figure 1. Study flow diagram.

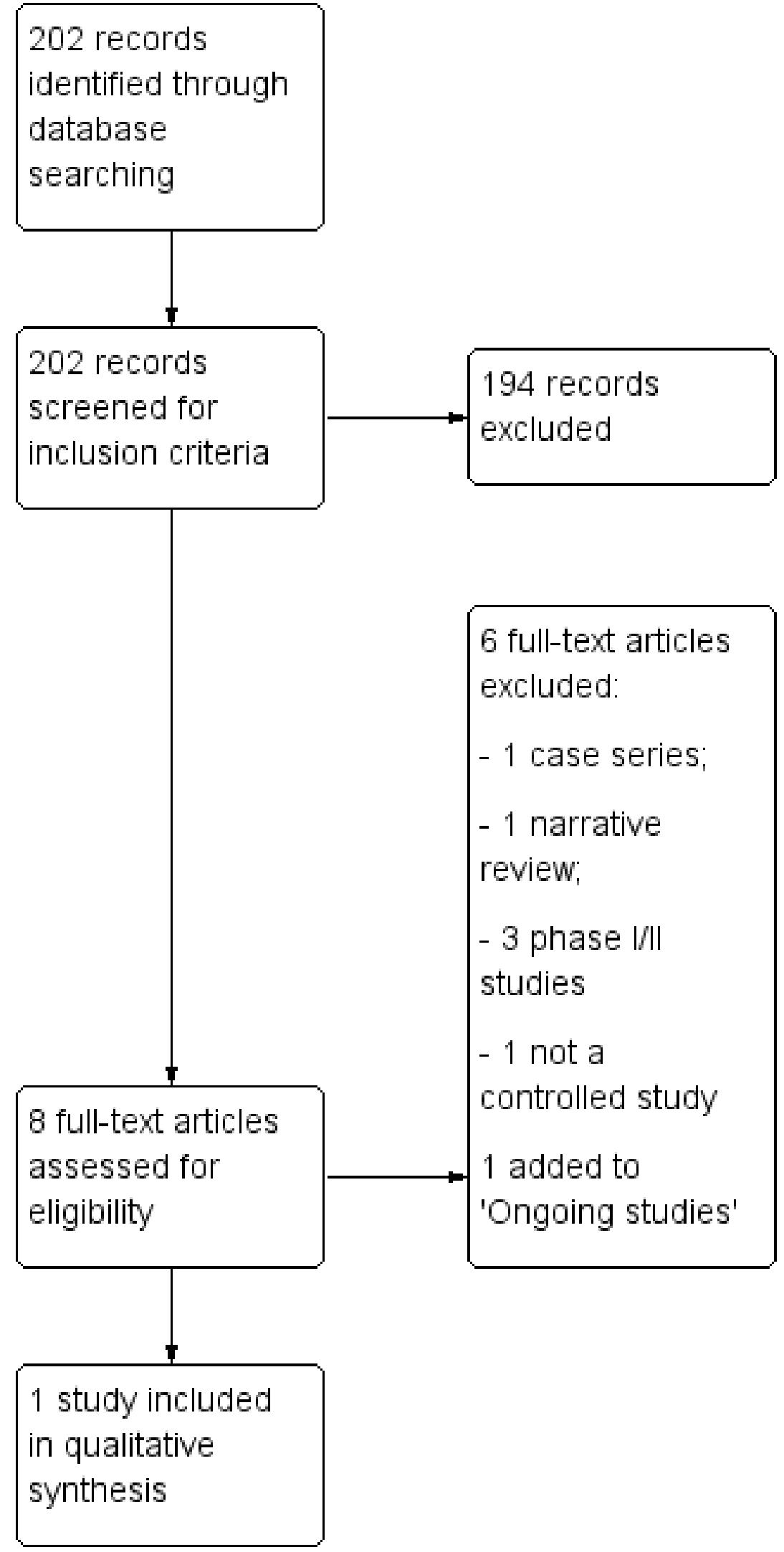




\section{Included studies}

\section{Trial design}

The included study was a multicentre, multi-national, doubleblind, randomised, placebo-controlled, 53-week, phase II/III study of the efficacy and safety of idursulfase $0.5 \mathrm{mg} / \mathrm{kg}$ administered either weekly or every-other week (EOW) in people with MPS II (Muenzer 2006).

\section{Participants}

The study included 96 people with MPS II. The biochemical evidence of MPS II included a documented deficiency in the I2S enzyme activity of less than or equal to $10 \%$ of the lower limit of the normal range measured in plasma, fibroblasts or leukocytes combined with a normal enzyme activity level of another sulfatase. All participants were required to reproducibly perform pulmonary function testing and have an abnormal FVC of less than $80 \%$ of predicted. Those individuals who had a tracheotomy or who had received a bone marrow or cord blood transplant were excluded from the study. All 96 randomised participants were male between the ages of 4.9 and 30.9 years. The mean (SD) age of participants in this study was 13.1 years (1.22), 14.4 years (1.20) and 15.1 years (1.11) for the placebo, idursulfase $0.5 \mathrm{mg} / \mathrm{kg}$ EOW and idursulfase $0.5 \mathrm{mg} / \mathrm{kg}$ weekly groups respectively. Nearly $45 \%$ of participants in the study were five to 11 years old and $25 \%$ were 19 years of age or older. There was no significant difference of age distribution among the three groups. Participants were also stratified according disease score, calculated using the baseline results of the 6MWT and the per cent predicted FVC (\% predicted FVC).

\section{Interventions}

The 96 participants were randomised in three groups: placebo ( $\mathrm{n}$ = 32); idursulfase $0.5 \mathrm{mg} / \mathrm{kg}$ weekly $(\mathrm{n}=32)$; and idursulfase 0.5 $\mathrm{mg} / \mathrm{kg}$ EOW $(\mathrm{n}=32)$. Infusions were given over a three-hour period and participants were discharged one hour after completing each infusion provided that they remained clinically stable.

\section{Outcomes}

The primary efficacy assessment of the included study was a comparison between the placebo and weekly idursulfase group for the change from baseline to week 53 in a single, two-component composite variable combining \% predicted FVC as a measure of respiratory function and 6MWT as a measure of physical functional capacity. The change from baseline to week 53 in \% predicted FVC and 6MWT for each participant was calculated. Within each parameter the changes were ranked irrespective of treatment group, with the lowest change value assigned a rank of 1 , the next lowest a rank of 2, and so forth. The two-component composite score for each participant was calculated by summing the ranks of the two individual components. The 6MWT was conducted in accordance with American Thoracic Society guidelines (ATS 2002). The secondary efficacy outcome measurements were: passive joint range of motion (JROM); liver and spleen volume by MRI and urinary GAG levels. Data were analysed using analysis of covariance with the treatment groups and study region fitted as factors and baseline participant age and baseline disease score as covariate. All analyses were performed by intention-to treat (ITT) and each variable was quantified as a change from the baseline value.

\section{Excluded studies}

A total of six studies were excluded (Gutiérrez-Solana 2007; Muenzer 2007; Muenzer 2016; Sohn 2013; Sohn 2015; TylkiSzymanska 2008). One because it was an abstract reporting partial results of an ongoing case-series study (Tylki-Szymanska 2008); one because it was a phase $\mathrm{I} / \mathrm{II}$ clinical trial that evaluated safety and dosing requirements (Muenzer 2007); one because it was a narrative review (Gutiérrez-Solana 2007); and one because it was a clinical trial phase I/II comparing a new formulation of the enzyme, Idursulfase beta, in two doses with the formulation of idursulfase currently available.

For further information, please refer to the Characteristics of excluded studies table.

\section{Risk of bias in included studies}

\section{Allocation}

Generation of randomisation sequence was not clear in the included study and we assessed this to have an unclear risk of bias (Muenzer 2006). Authors state that the randomisation was stratified by age and total disease score at baseline.

Allocation concealment was not discussed in the study, which therefore has been categorized as having an unclear risk of bias.

\section{Blinding}

The study was double-blind, and all participants received weekly intravenous infusions. Participants randomised to EOW idursulfase dosing received placebo infusion during intervening weeks to maintain blinding. The primary outcome assessment was conducted by a professional who was not involved with the study. We therefore judged the study to have a low risk of bias for blinding of participants, clinicians and outcome assessors.

\section{Incomplete outcome data}

Ninety-four (97.9\%) of 96 participants completed one year of treatment. The two participants, who did not complete one year of treatment, died during the study: one participant in the placebo group; and one participant in the idursulfase weekly group. Neither death was considered by the investigators to be related to the study drug and analysis was done on an intention-to-treat basis. We have therefore assessed this domain as having a low risk of bias.

\section{Selective reporting}

There is concern about selective reporting, due to important clinical outcomes (e.g. $z$ score of height and weight, left ventricular mass index and overnight $\mathrm{AHI}$ ) not being evaluated and we have assessed this domain as having an unclear risk of bias.

\section{Other potential sources of bias}

We believe that the study was free of other problems that could put it at a high risk of bias.

\section{Effects of interventions}

In the only included study, participants were randomised into three groups, idursulfase $0.5 \mathrm{mg} / \mathrm{kg}$ weekly, EOW and placebo. To evaluate the effect of each treatment the same placebo group was presented in each subgroup in the meta-analyses graphs. 


\section{Primary outcomes}

\section{Z scores for height and weight}

This outcome was not reported in the included study.

\section{Six-minute walk test (6MWT)}

Following 53 weeks of treatment, participants in the weekly idursulfase $0.5 \mathrm{mg} / \mathrm{kg}$ group demonstrated a significant improvement rate compared with placebo of the primary outcome: distance walked in six minutes (6MWT) on the basis of change from baseline, MD 37.00 (95\% Cl 6.52 to 67.48 ). The EOW idursulfase $0.5 \mathrm{mg} / \mathrm{kg}$ group also showed an improvement but this was not significant compared with placebo, MD $23.00(95 \% \mathrm{Cl}-4.49$ to 50.49$)$ (Analysis 1.1) (Figure 2).

Figure 2. Forest plot of comparison: 1 Idursulfase $0.5 \mathrm{mg} / \mathrm{kg}$ versus placebo, outcome: 1.1 Primary outcome: Sixminute walk test (6MWT).

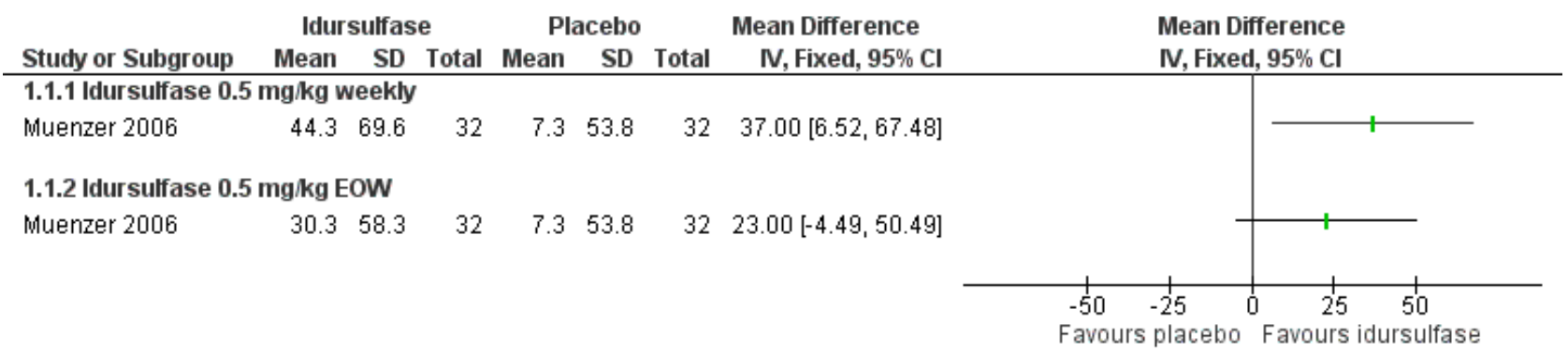

\section{Secondary outcomes}

\section{Lung function}

a. FEV $_{1}$

This outcome was not reported in the included study.

\section{b. FVC}

Changes from baseline in \% predicted FVC and absolute FVC were reported (Muenzer 2006). After 53 weeks, there was no statistical significance difference in \% predicted FVC between the weekly idursulfase group and the placebo group, MD $2.70(95 \% \mathrm{Cl}-2.12$ to 7.52) or in the EOW idursulfase group compared with placebo group, MD -0.75 (95\% Cl -4.98 to 3.49) (Analysis 1.2).

Absolute FVC was significantly increased from baseline in the weekly dosing group compared to placebo, MD 0.16 ( $95 \% \mathrm{Cl} 0.05$ to 0.27 ) after 53 weeks. No difference was observed in absolute FVC between the EOW idursulfase group and placebo, MD $0.01(95 \% \mathrm{Cl}$ -0.07 to 0.09 ) (Analysis 1.3).

\section{c. Any other measure of lung function}

No other measure of lug function was reported in the included study.

\section{Overnight apnea-hypopnea index (AHI)}

This outcome was not reported in the included study.

\section{Left ventricular mass index}

This outcome was not reported in the included study.

\section{Joint mobility score}

The included study measured changes in passive joint range of motion (JROM) (Muenzer 2006). The authors reported that there were no significant differences between treatment groups but the values observed were not published.

\section{Liver and spleen volume}

The study reported changes from baseline in the liver and spleen volume determined by magnetic resonance imaging (MRI) using the same imaging protocol at all sites (Muenzer 2006). After 53 weeks, in the ITT population, liver volume changed statistically significantly in both idursulfase treatment groups (weekly and EOW) compared with the change in the placebo group, MD $-24.50(95 \% \mathrm{Cl}-28.94$ to -20.06$)$ and $\mathrm{MD}-23.20(95 \% \mathrm{Cl}-27.78$ to -18.62$)$ respectively (Analysis 1.5).

After 53 weeks in the ITT population, spleen volume were significantly reduced in the idursulfase groups compared to placebo, MD -32.30 (95\% IC -41.79 to -22.81 ) in the weekly group; MD -27.00 (95\% IC -37.35 to -16.65$)$ in the idursulfase EOW group (Analysis 1.6).

\section{Quality of life}

This outcome was not reported in the included study.

\section{Pain}

This outcome was not reported in the included study.

\section{Rate of hospitalizations}

This outcome was not reported in the included study.

\section{Resources required for home care support}

This outcome was not reported in the included study.

\section{Changes in glycosaminoglycans (GAGs) urinary excretion}

Changes from baseline in the GAGs urinary excretion were measured in the included study (Muenzer 2006). Urine GAGs levels decreased in participants treated with either dosing regimen of idursulfase and did not change significantly in participants treated with placebo. At week 53, the changes in the GAGs levels in the idursulfase groups (weekly and EOW) were significantly different than that of the placebo group, MD $-207.40(95 \% \mathrm{Cl}-284.85$ to 
$-129.95)$ and $\mathrm{MD}-173.20(95 \% \mathrm{Cl}-240$ to -105.56$)$ respectively (Analysis 1.7).

\section{Developmental score}

This outcome was not reported in the included study.

\section{Audiologic assessment}

This outcome was not reported in the included study.

\section{Age at death}

Two deaths occurred during the study (Muenzer 2006). A 24-yearold male in the idursulfase weekly group developed a pulmonary infection, respiratory insufficiency and had a cardiac arrest five days after his first infusion, and he experienced a fatal cardiac arrest seven days later. A second participant, a six-year-old male, who was randomised to placebo developed streptococcus pneumonia following his $34^{\text {th }}$ dose of blinded-study medication, and suffered a lung haemorrhage followed by a fatal cardiac arrest eight days later. The study investigator did not consider either death as being related to the study medication.

\section{Adverse effects and toxicity of treatment}

No participant was reported to withdraw from the study due to adverse effects (AE). The incidence of AEs were similar across treatment groups within the trial (Muenzer 2006). The most frequently reported AEs during the study (with a excess incidence of at least a 9\% compared with placebo in either idursulfase treated group) included headache, nasopharyngitis, abdominal pain, arthralgia and pruritus. All were considered to be consistent with those expected to be seen in an untreated MPS II population. The majority of AEs were reported as mild or moderate in severity in all groups.

Of the AEs considered to be possibly related to idursulfase treatment, the most common were infusion-related. An infusionrelated $A E$ was defined as occurring within a day after the infusion began and was judged by the investigator to be possibly or probably related to study treatment. A similar number of participants in each treatment group experienced one or more infusion-related AEs during the study, RR $1.05(95 \% \mathrm{Cl} 0.74$ to 1.48$)$ in the weekly group compared to placebo and RR 1.05 (95\% Cl 0.74 to 1.48 ) in the EOW group (Analysis 1.8). The incidence of infusion-related AEs was maximal between weeks four and 12 and decreased in all three groups thereafter. Infusion-related AEs reported in the placebo group were similar in nature and severity to those in the idursulfase-treated groups. No participant withdrew from the study because of infusion-related AEs.

A total of 49 serious adverse events (SAEs) occurred in 26 participants during the study: nine participants in the placebo group experienced a total of 18 SAEs; eight participants in the idursulfase EOW group experienced a total of 18 SAEs, RR 1.00 $(95 \% \mathrm{Cl} 0.65$ to 1.54$)$; and nine participants in the idursulfase weekly group experienced a total of 13 SAEs, RR $0.72(95 \% \mathrm{Cl}$ 0.43 to 1.21) (Analysis 1.9). The majority of these SAEs were considered unrelated to the blinded study medication, although three participants experienced SAEs that were considered by the investigators to be probably or possibly related to the study drug.

Investigators detected IgG anti-idursulfase antibodies in 15 participants $(46.9 \%)$ in the idursulfase weekly group and in
15 participants $(46.9 \%)$ in the idursulfase EOW group. In two participants (one from each active treatment group) IgM antibodies were found. The highest prevalence of IgG antibodies was seen at week 27 of the study, when $44.4 \%$ of the participants treated with idursulfase were antibody-positive. After 53 weeks, $31.7 \%$ of participants in the idursulfase groups remained antibody-positive. The reduction in urine GAG levels in antibody-positive participants was approximately two-thirds of that seen in antibody-negative participants. There was no association with the presence of antibodies and AEs.

\section{Other results}

\section{Composite score (\% predicted FVC + 6MWT)}

The efficacy endpoint in the trial included was change from baseline to week 53 in a two-component composite score combining \% predicted FVC as a measure of respiratory function and the 6MWT as a measure of functional capacity (Muenzer 2006). The two-component composite score of the idursulfase $0.5 \mathrm{mg} / \mathrm{kg}$ weekly group was significantly higher than in the placebo group in the intent-to-treat population, MD 18.96 (95\% Cl 6.28 to 31.64). A smaller difference was found for the idursulfase EOW compared to placebo groups in the intent-to-treat population, MD 12.86 (95\% $\mathrm{Cl} 0.77$ to 24.95) (Analysis 1.4). The trial authors reported that the responses between the two idursulfase treatment groups were not significantly different, treatment difference being $10.84 \pm 7.11, \mathrm{P}=$ 0.1329).

\section{DISCUSSION}

\section{Summary of main results}

The evidence available so far are limited to only one randomised clinical trial (Muenzer 2006).The results of the study included in this review show a short-term clinical benefit in people treated with idursulfase compared with those treated with placebo. After 53 weeks of treatment, participants in the weekly idursulfase 0.5 $\mathrm{mg} / \mathrm{kg}$ group demonstrated a statistically significant improvement rate compared with placebo in the distance walked in six minutes (6MWT), mean difference (MD) 37.00 (95\% Cl 6.52 to 67.48). The every-other week (EOW) group also showed improvement but not significant compared with placebo, MD $23.00(95 \% \mathrm{Cl}-4.49$ to 50.49). There was no statistically significant difference in per cent predicted forced vital capacity (FVC) between the three groups and absolute FVC was significantly increased from baseline in the weekly dosing group compared to placebo, MD $0.16(95 \% \mathrm{Cl} 0.05$ to 0.27 ). In addition, urine glycosaminoglycan (GAG) excretion and liver and spleen volumes were significantly reduced from baseline by both idursulfase dosing regimens.

Idursulfase was generally well tolerated, and the majority of treatment-emergent adverse events were consistent with the natural history of untreated mucopolysaccharidosis (MPS) II. The most common treatment-related adverse events were infusion related. Idursulfase antibodies were detected in $31.7 \%$ of participants at the end of the study and were related to smaller reduction in urine GAG levels.

It is known that controlled studies in rare diseases are difficult to be conducted and so far only results of observational studies are available or ongoing. Results from two case series studies have been published in recent years. One reports the experience of enzyme replacement therapy with idursulfase in six children 
under five years old (Alcade-Martín 2010). The children began treatment with a mean age of 3.6 years and were followed for a mean period of nine months. Decreased levels of urinary GAG were observed, also some improvement in the volume of the liver and spleen; in addition, joint mobility stabilized or improved during treatment. Growth rate remained normal as expected; in untreated individuals with MPS II, growth decelerates at around age four or five years. With regards to safety, only mild drug-related infusion reactions were noted. The second study assessed the overall result of enzyme replacement therapy on the growth of 18 participants (nine under 10 years of age and nine over) followed for more than three years (Schulze-Frenking 2011). All children under 10 years of age (except one who had short stature at baseline) grew at normal rate during this period. Those over 10 years of age also showed an increase in growth rate in the first two years of treatment, which decreased in the third year. The authors suggested this may be due to puberty. This study indicates that therapy may have a positive effect on growth rate especially when initiated before 10 years of age. In the latest searches undertaken for the update of this review, a further observational study was identified (Jones 2013). The study investigated the effects of enzyme replacement therapy with idursulfase on growth in people with MPS II enrolled in the the Hunter Outcome Survey (HOS), a multinational database. A total of 133 people ( 8 to 15 years of age at treatment start) with data on height available on more than one occasion within 24 months of treatment start were included. Results showed that the growth velocity after treatment was significantly improved compared with before treatment. Analysis of a covariate showed a significant negative influence on growth of mutation type (individuals with deletions or large rearrangements or nonsense mutations) and age (12 to 15 years). Cognitive involvement, pubertal status and functional classification were found not be be related to the growth deficit or response to treatment.

It is noteworthy that in the Schulze-Frenking study one child younger than 10 years of age, who already had short stature at baseline, showed poor response in growth rate with treatment. The study authors suggested that this may be related to the development of antibodies (Schulze-Frenking 2011). The study does not provide more data on safety and the proportion of individuals who developed antibodies. From an immunological perspective, the effect of neutralizing antibodies on efficacy is still to be fully evaluated; therefore, no firm conclusions can be drawn about the effect of neutralizing activity on the safety and efficacy of idursulfase.This factor should be carefully evaluated in other studies with long-term follow-up,

While enzyme replacement therapy with idursulfase has been shown to have biologic effects and may improve the functional capacity in people with MPS II, the clinical significance of these effects is not clear. The treatment improves the distance walked in six minutes (6MWD) but the average improvement is small with wide confidence intervals. Idursulfase has not been shown to improve clinically relevant outcomes such as quality of life, pain, rate of hospitalisation, resources required for home care support and mortality.

\section{Overall completeness and applicability of evidence}

The included study provided data on the efficacy and safety of short-term (53 weeks) enzyme replacement therapy with idursulfase for people with MPS II (aged five to 31 years). The results of the open-label extension study have recently been published
(Muenzer 2011). All individuals who completed the double-blinded study received idursulfase $0.5 \mathrm{mg} / \mathrm{kg}$ weekly for two years. There were no improvements in the per cent predicted FVC, only in the absolute FVC, which probably reflected the growth that has occurred in those younger than 18 years of age during treatment, since this increase was not observed in those aged over 18 years. Increases in the 6MWT remained stable and mean liver and spleen volumes remained reduced. Mean joint range of motion improved only for the shoulder joint. All participants experienced adverse effects, with $59.6 \%$ experiencing at least one drug-related adverse effect, $53 \%$ an infusion-related adverse effect, $28.7 \%$ at least one severe or life-threatening adverse effect. Neutralizing IgG antibodies were detected in $27.1 \%$ of the participants at the end of the extension study and seemed to attenuate the improvement in pulmonary function. Participants in the study had to be able to follow instructions and perform the test of the primary endpoint (6MWT and per cent predicted FVC) which suggests that the individuals included were not representative of those with advanced forms of the disease. The drug may achieve improvement of the physical condition, a decrease of organomegaly and urinary excretion of GAGs, but the overall benefit should be evaluated according to global somatic involvement, overall rate of disease progression in central nervous system and on variables such as improved length of survival.

\section{Quality of the evidence}

The quality of the included study was considered good, although we note the absence within the study report of information as to how both the allocation generation and concealment were performed.

\section{Potential biases in the review process}

There is concern about selective reporting, due to important clinical outcomes (e.g. growth velocity, left ventricular mass index and overnight apnoea-hypopnoea index not being evaluated in the included study.

\section{AUTHORS' CONCLUSIONS}

\section{Implications for practice}

The current evidence is limited. While the randomised clinical trial identified was considered of good quality, it failed to describe important outcomes. It has been demonstrated that enzyme replacement therapy with idursulfase is effective in relation to functional capacity (6MWT and per cent predicted FVC), liver and spleen volumes and urine GAG excretion in people with MPS II compared with placebo. There is no available evidence in the included study or in the wider literature on outcomes such as sleep apnoea, cardiac function, quality of life and mortality. More studies are needed to obtain more information on the long-term effectiveness and safety of enzyme replacement therapy.

\section{Implications for research}

Further trials, including rigorous multi-domain follow up of participants receiving treatment, are needed to determine the longterm effects of enzyme replacement therapy. Clinically relevant outcomes should be assessed, such as improvements in cardiac function, respiratory function, including sleep apnoea, stabilization of skeletal abnormality, quality of life, need of hospitalizations and mortality. The effects of immunogenicity on the safety and 
effectiveness of enzyme replacement therapy with idursulfase need to be better studied.

The effects of enzyme replacement therapy with idursulfase in children under five years of age need to be further investigated, given that the early introduction of therapy with consequent limitation of the formation of lysosomal storage can potentially lead to better outcomes in the evolution of the disease.

\section{ACKNOWLEDGEMENTS}

We would like to thank Tracey Remmington and Nikki Jahnke from the Cochrane Cystic Fibrosis and Genetic Disorders Group for their extensive collaboration. 


\section{R E F E R E N C E S}

\section{References to studies included in this review}

\section{Muenzer 2006 \{published data only\}}

Beck M, Wraith E, Muenzer J, Giugliani R, Harmatz P, Eng CM, et al. Long-term weekly dosing of idursulfase in the treatment of mucopolysaccharidosis II (MPS II, Hunter syndrome) [abstract]. Journal of Inherited Metabolic Disease 2007;30(Suppl 1):116.

Muenzer J, Beck M, Eng CM, Giugliani R, Harmatz P, Martin R, et al. Long-term, open-labeled extension study of idursulfase in the treatment of Hunter syndrome. Genetics in Medicine 2011;13(2):95-101.

Muenzer J, Wraith E, Beck M, Giugliani R, Harmatz P, Eng CM, et al. Clinical benefit of enzyme replacement therapy (ERT) in mucopolysaccharidosis II (MPS II, Hunter syndrome) [abstract]. Journal of Inherited Metabolic Disease 2006;29(Suppl 1):28.

* Muenzer J, Wraith JE, Beck M, Giugliani R, Harmatz P, Eng CM, et al. A phase II/III clinical study of enzyme replacement therapy with idursulfase in mucopolysaccharidosis II (Hunter syndrome). Genetics in Medicine 2006;8(8):465-73.

\section{References to studies excluded from this review}

Gutiérrez-Solana 2007 \{published data only\}

Gutiérrez-Solana LG. Clinical study of enzyme replacement therapy with idursulfase. Revista de Neurologia 2007;44(Suppl 1):S7-S11.

\section{Muenzer 2007 \{published data only\}}

Muenzer J, Calikoglu MG, Conway AM, Kimura A. The longterm experience of enzyme replacement therapy for Hunter syndrome (MPS II) [abstract]. Journal of Inherited Metabolic Disorder 2005;28(Suppl 1):188.

* Muenzer J, Gucsavas-Calikoglu M, McCandless SE, Schuetz TJ, Kimura A. A phase I/II clinical trial of enzyme replacement therapy in mucopolysaccharidosis II (Hunter syndrome). Molecular Genetics and Metabolism. 2007;90(3):329-37.

Muenzer J, Towle D, Calikoglu M, McCandless S. The 12-month experience of enzyme replacement for mucopolysaccharidosis II (Hunter syndrome) [abstract]. Journal of Inherited Metabolic Disease 2003;26(Suppl 2):144.

\section{Muenzer 2016 \{published data only\}}

Muenzer J, Hendriksz CJ, Fan Z, Vijayaraghavan S, Perry V4, Santra S, et al. A phase I/II study of intrathecal idursulfase-IT in children with severe mucopolysaccharidosis II. Genetics in Medicine 2016;18(1):73-81.

\section{Sohn 2013 \{published data only\}}

Sohn YB, Cho SY, Park SW, Kim SJ, Ko AR, Kwon EK, et al. Phase I/II clinical trial of enzyme replacement therapy with idursulfase beta in patients with mucopolysaccharidosis II (Hunter Syndrome) [abstract]. Journal of Inherited Metabolic Disease 2013;36 Suppl 2:S260, Abstract no: P-565. [CENTRAL: 977628; CRS: 5500125000000518]
Sohn YB, Cho SY, Park SW, Kim SJ, Ko AR, Kwon EK, et al. Phase I/II clinical trial of enzyme replacement therapy with idursulfase beta in patients with mucopolysaccharidosis II (Hunter syndrome). Orphanet Journal of Rare Diseases 2013;8:42. [DOI: 10.1186/1750-1172-8-42]

Sohn 2015 \{published data only\} Sohn YB, Cho SY, Lee J, Kwun Y, Huh R, Jin DK. Safety and efficacy of enzyme replacement therapy with idursulfase beta in children aged younger than 6 years with Hunter syndrome. Molecular Genetics and Metabolism 2015;114(2):156-60.

Tylki-Szymanska 2008 \{published data only\} Tylki-Szymanska A, Giugliani R, Hwu WL. A clinical trial of idursulfase in Hunter syndrome patients 5 years old and younger [abstract]. Journal of Inherited Metabolic Disease 2008;31(Suppl 1):130.

\section{References to ongoing studies}

\section{NCT02055118 \{published data only\}}

NCT02055118. A controlled, randomized, two-arm, open-label, assessor-blinded, multicenter study of intrathecal idursulfase-IT administered in conjunction with elaprase ${ }^{\circledast}$ in pediatric patients with Hunter syndrome and early cognitive impairment. https:// clinicaltrials.gov/ct2/show/NCT02055118 (accessed 20 Jan 2016).

\section{Additional references}

\section{Alcade-Martín 2010}

Alcalde-Martín C, Muro-Tudelilla JM, Cancho-Candela R, Gutiérrez-Solana LG, Pintos-Morell G, Martí-Herrero M, et al. First experience of enzyme replacement therapy with idursulfase in Spanish patients with Hunter syndrome under 5 years of age: Case observations from the Hunter Outcome Survey (HOS). European Journal of Medical Genetics 2010;53(6):371-7.

\section{ATS 2002}

American Thoracic Society. ATS statement: guidelines for the six-minute walk test. American Journal of Respiratory and Critical Care Medicine 2002;166(1):111-7.

\section{de Jong 1992}

de Jong JG, Wevers RA, Liebrand-van Sambeek R. Measuring urinary glycosaminoglycans in the presence of protein: an improved screening procedure for mucopolysaccharidoses based on dimethylmethylene blue. Clinical Chemistry 1992;38(6):803-7.

\section{Elbourne 2002}

Elbourne DR, Altman DG, Higgins JP, Curtin F, Worthington HV, Vail A. Meta-analyses involving cross-over trials: methodological issues. International Journal of Epidemiology 2002;31(1):140-9. [PUBMED: 11914310] 


\section{Higgins 2003}

Higgins JPT, Thompson SG, Deeks JJ, Altman DG. Measuring inconsistency in meta-analysis. BMJ 2003;327(7414):555-7.

\section{Higgins 2011a}

Higgins JPT, Altman DG. Chapter 8: Assessing risk of bias in included studies. In: Higgins JPT, Green S (editors). Cochrane Handbook for Systematic Reviews of Interventions Version 5.1 [updated March 2011]. The Cochrane Collaboration, 2011. Available from www.cochrane-handbook.org.

\section{Higgins 2011b}

Higgins JPT, Deeks JJ, Altman DG. Chpater 16: Special topics in statistics. Intention to treat issues. In: Higgins JPT, Green $\mathrm{S}$ (editors). Cochrane Handbook for Systematic Reviews of Interventions Version 5.1 [updated March 2011]. The Cochrane Collaboration, 2011. Available from www.cochranehandbook.org.

\section{Jones 2008}

Jones SA, Almássy Z, Beck M, Burt K, Clarke JT, Giugliani R, et al. Mortality and cause of death in mucopolysaccharidosis type II-a historical review based on data from the Hunter Outcome Survey (HOS). Journal of Inherited Metabolic Disease 2008;32(4):534-43.

\section{Jones 2013}

Jones SA, Parini R, Harmatz P, Giugliani R, Fang J, Mendelsohn NJ, et al. The effect of idursulfase on growth in patients with Hunter syndrome: data from the Hunter Outcome Survey (HOS). Molecular Genetics and Metabolism 2013;109(1):41-8.

\section{Kresse 1982}

Kresse H, von Figura K, Klein U, Glossl J, Paschke E, Pohlmann R. Enzymic diagnosis of the genetic mucopolysaccharide storage disorders. Methods in Enzymology 1982;83:559-72.

\section{Martin 2008}

Martin R, Beck M, Eng C, Giugliani R, Harmatz P, Munoz V, et al. Recognition and Diagnosis of Mucopolysaccharidosis II (Hunter Syndrome). Pediatrics 2008;121(2):e377-86.

\section{Meikle 1999}

Meikle PJ, Hopwood JJ, Clague AE, Carey WF. Prevalence of lysosomal storage disorders. JAMA 1999;281(3):249-54.

\section{Muenzer 2011}

Muenzer J, Beck M, Eng CM, Giugliani R, Harmatz P, Martin R, et al. Long-term, open-labeled extension study of idursulfase in the treatment of Hunter syndrome. Genetics in Medicine 2011;13(2):95-101.

\section{National Horizon Scanning Centre 2005}

National Horizon Scanning Centre. New and Emerging Technology Briefing: Iduronate-2-sulfatase for Hunter Syndrome. The University of Birmingham 2005.

\section{Neufeld 2001}

Neufeld EF, Muenzer J. The mucopolysaccharidoses. The Metabolic and Molecular Bases of Inherited Disease. New York, NY: McGraw-Hill, 2001:3421-52.

\section{Schulze-Frenking 2011}

Schulze-Frenking G, Jones SA, Roberts J, Beck M, Wraith JE. Effects of enzyme replacement therapy on growth in patients with mucopolysaccharidosis type II. Journal of Inherited Metabolic Disease 2011;34(1):203-8.

\section{Tuschl 2005}

Tuschl K, Gal A, Paschke E, Kircher S, Bodamer OA. Mucopolysaccharidosis type II in females: case report and review of literature. Pediatric Neurology 2005;32(4):270-2.

\section{Vellodi 2007}

Vellodi A, Wraith JE, Cleary M, Ramaswami U, Lavery C, Jessop $E$. Guidelines for the investigation and management of patients with mucopolysaccharidosis type II. www.specialisedservices.nhs.uk/library/23/Guidelines_for_ Mucopolysaccharidosis_Type_II.pdf (accessed September 2009).

\section{Wraith 2008a}

Wraith JE, Scarpa M, Beck M, Bodamer OA, De Meirleir L, Guffon N, et al. Mucopolysaccharidosis type II (Hunter syndrome): a clinical review and recommendations for treatment in the era of enzyme replacement therapy. European Journal of Pediatrics 2008;167(3):267-77.

\section{Wraith 2008b}

Wraith JE. Enzyme replacement therapy with idursulfase in patients with mucopolysaccharidosis type II. Acta Paediatrica. Supplementum 2008;97(497):76-8.

\section{Young 1983}

Young ID, Harper PS. The natural history of the severe form of Hunter's syndrome: a study based on 52 cases. Developmental Medicine and Child Neurology 1983;25(4):481-9.

\section{References to other published versions of this review da Silva 2011 \\ da Silva EMK, da Silva EMK, Strufaldi MWL, Andriolo RB, Silva LA. Enzyme replacement therapy with idursulfase for mucopolysaccharidosis type II (Hunter syndrome). Cochrane Database of Systematic Reviews 2011, Issue 11. [DOI: 10.1002/14651858.CD008185.pub2] \\ da Silva 2014 \\ da Silva EMK, Strufaldi MWL, Andriolo RB, Silva LA. Enzyme replacement therapy with idursulfase for mucopolysaccharidosis type II (Hunter syndrome). Cochrane Database of Systematic Reviews 2014, Issue 1. [DOI: 10.1002/14651858.CD008185.pub3]}

* Indicates the major publication for the study 
CHARACTERISTICS OF STUDIES

Characteristics of included studies [ordered by study ID]

Muenzer 2006

Methods Multicentre, multinational, double-blind, randomised, placebo-controlled, 53-week clinical trial.

Participants

Participants between the ages of 5 and 31 years with a diagnosis of MPS II based on both clinical and biochemical criteria were enrolled in the study. Clinical criteria included having any one of the following MPS II-related abnormalities: hepatosplenomegaly; radiographic evidence of dysostosis multiplex; valvular heart disease; or evidence of obstructive airway disease. The biochemical evidence of MPS II included a documented deficiency in I2S enzyme activity of $10 \%$ of the lower limit of the normal range as measured in plasma, fibroblasts, or leukocytes combined with a normal enzyme activity level of another sulfatase. At baseline all participants were required to reproducibly perform pulmonary function testing and have an abnormal FVC of $80 \%$ of predicted. Participants who had a tracheostomy or who had received a bone marrow or cord blood transplant were excluded from the study.

Interventions Intravenous infusions of idursulfase weekly or EOW at a dose of $0.5 \mathrm{mg} / \mathrm{kg}$, or weekly infusions of placebo.

Outcomes The primary efficacy endpoint in the trial measured changes from baseline to week 53, combining $\%$ predicted FVC as a measure of respiratory function and the 6MWT as a measure of functional capacity. The 6MWT was conducted in accordance with ATS guidelines. The secondary efficacy outcome measurements were: passive JROM; liver and spleen volume by MRI; urinary GAG levels and cardiac LVM by echocardiography. All measurements were made at baseline, weeks 18, 36 and 53.

Notes

\section{Risk of bias}

\begin{tabular}{lll}
\hline Bias & Authors' judgement & Support for judgement \\
\hline $\begin{array}{l}\text { Random sequence genera- } \\
\text { tion (selection bias) }\end{array}$ & Unclear risk & $\begin{array}{l}\text { We found no information about generation of randomisation sequence. Partic- } \\
\text { ipants randomised equally to } 1 \text { of } 3 \text { treatment arms, randomisation was strati- } \\
\text { fied by age and total disease score at baseline data. }\end{array}$
\end{tabular}

\begin{tabular}{lll}
\hline $\begin{array}{l}\text { Allocation concealment } \\
\text { (selection bias) }\end{array}$ & Unclear risk & Not cited. \\
\hline $\begin{array}{l}\text { Blinding (performance } \\
\text { bias and detection bias) }\end{array}$ & Low risk & $\begin{array}{l}\text { All participants received intravenous infusion weekly. Participants randomised } \\
\text { to EOW idursulfase dosing received placebo infusion during intervening weeks } \\
\text { to maintain blinding. }\end{array}$ \\
\hline
\end{tabular}

Incomplete outcome data Low risk (attrition bias)

94 (97.9\%) of 96 participants completed 1 year of treatment. The two partic-

All outcomes ipants who did not complete one year of treatment died during the study: 1 participant in the placebo group and 1 participant in the idursulfase weekly group. Neither death was considered by the investigator to be related to the study drug.

\begin{tabular}{lll}
\hline $\begin{array}{l}\text { Selective reporting (re- } \\
\text { porting bias) }\end{array}$ & Unclear risk & $\begin{array}{l}\text { There are concern about selective reporting, due important clinical outcomes } \\
\text { (e.g. LVM index and overnight AHI) were not evaluated. }\end{array}$ \\
\hline Other bias & Low risk & $\begin{array}{l}\text { The study apparently was free of other problems that could put it at a high risk } \\
\text { of bias }\end{array}$
\end{tabular}

6MWT: 6-minute-walk-test

AHI: apnoea-hypopnoea index

ATS: American Thoracic Society 
EOW: every other week

FVC: forced vital capacity

JROM: joint range of motion

I2S: iduronate-2-sulfatase

LVM: left ventricular mass

MRI: magnetic resonance imaging

Characteristics of excluded studies [ordered by study ID]

\begin{tabular}{ll}
\hline Study & Reason for exclusion \\
\hline Gutiérrez-Solana 2007 & Narrative review. \\
\hline Muenzer 2007 & Phase I/II clinical trial that evaluated safety and dosing requirements in 12 people. \\
\hline Muenzer 2016 & $\begin{array}{l}\text { Phase I/II clinical trial that evaluated safety and dosing requirements of intrathecal idursulfase. No } \\
\text { outcomes of interest. }\end{array}$ \\
\hline Sohn 2013 & $\begin{array}{l}\text { Phase I/II clinical trial comparing a new formulation (idursulfase beta) with the formulation of idur- } \\
\text { sulfase currently available. }\end{array}$ \\
\hline Sohn 2015 & Not a controlled study. \\
\hline Tylki-Szymanska 2008 & Ongoing case series. \\
\hline
\end{tabular}

Characteristics of ongoing studies [ordered by study ID]

\section{NCT02055118}

\begin{tabular}{|c|c|}
\hline Trial name or title & $\begin{array}{l}\text { A controlled, randomized, two-arm, open-label, assessor-blinded, multicenter study of intrathe- } \\
\text { cal idursulfase-IT administered in conjunction with Elaprase }{ }^{\circledast} \text { in pediatric patients with Hunter syn- } \\
\text { drome and early cognitive impairment. }\end{array}$ \\
\hline Methods & Randomized parallel, open label study. \\
\hline Participants & $\begin{array}{l}\text { Participant male, } \geq 3 \text { and }<18 \text { years of age with documented diagnosis of MPS II, evidence at } \\
\text { screening of Hunter syndrome-related cognitive impairment and has received and tolerated a min- } \\
\text { imum of } 4 \text { months of therapy with Elaprase }{ }^{\circledast} \text { during the period immediately prior to screening. }\end{array}$ \\
\hline Interventions & $\begin{array}{l}\text { Intervention: idursulfase-IT } 10 \mathrm{mg} \text { using intrathecal drug delivery device once a month for } 52 \\
\text { weeks. Control: standard care. }\end{array}$ \\
\hline Outcomes & $\begin{array}{l}\text { Change from baseline in the GCA score after } 12 \text { months of treatment at visit week } 52 \text {, as obtained } \\
\text { by DAS-II testing. }\end{array}$ \\
\hline Starting date & 17 January 2014. \\
\hline Contact information & MedInfo Shire HGT US_ShireHGT_Medicalinformation@shire.com. \\
\hline
\end{tabular}


DATA AND ANALYSES

\section{Comparison 1. Idursulfase $0.5 \mathrm{mg} / \mathbf{k g}$ versus placebo}

\begin{tabular}{|c|c|c|c|c|}
\hline Outcome or subgroup title & No. of studies & $\begin{array}{l}\text { No. of partici- } \\
\text { pants }\end{array}$ & Statistical method & Effect size \\
\hline $\begin{array}{l}1 \text { Six-minute walk test (6MWT) } \\
\text { (53 weeks) }\end{array}$ & 1 & & Mean Difference (IV, Fixed, 95\% CI) & $\begin{array}{l}\text { Totals not select- } \\
\text { ed }\end{array}$ \\
\hline $\begin{array}{l}1.1 \text { Idursulfase } 0.5 \mathrm{mg} / \mathrm{kg} \text { week- } \\
\text { ly }\end{array}$ & 1 & & Mean Difference (IV, Fixed, 95\% CI) & $0.0[0.0,0.0]$ \\
\hline 1.2 Idursulfase $0.5 \mathrm{mg} / \mathrm{kg}$ EOW & 1 & & Mean Difference (IV, Fixed, 95\% CI) & $0.0[0.0,0.0]$ \\
\hline $2 \%$ predicted FVC (53 weeks) & 1 & & Mean Difference (IV, Fixed, 95\% CI) & $\begin{array}{l}\text { Totals not select- } \\
\text { ed }\end{array}$ \\
\hline $\begin{array}{l}2.1 \text { Idursulfase } 0.5 \mathrm{mg} / \mathrm{kg} \text { week- } \\
\text { ly }\end{array}$ & 1 & & Mean Difference (IV, Fixed, 95\% CI) & $0.0[0.0,0.0]$ \\
\hline 2.2 Idursulfase $0.5 \mathrm{mg} / \mathrm{kg}$ EOW & 1 & & Mean Difference (IV, Fixed, 95\% CI) & $0.0[0.0,0.0]$ \\
\hline 3 Absolute FVC (L) (53 weeks) & 1 & & Mean Difference (IV, Fixed, 95\% CI) & $\begin{array}{l}\text { Totals not select- } \\
\text { ed }\end{array}$ \\
\hline $\begin{array}{l}3.1 \text { Idursulfase } 0.5 \mathrm{mg} / \mathrm{kg} \text { week- } \\
\text { ly }\end{array}$ & 1 & & Mean Difference (IV, Fixed, 95\% CI) & $0.0[0.0,0.0]$ \\
\hline 3.2 Idursulfase $0.5 \mathrm{mg} / \mathrm{kg}$ EOW & 1 & & Mean Difference (IV, Fixed, 95\% CI) & $0.0[0.0,0.0]$ \\
\hline $\begin{array}{l}46 \mathrm{MWT}+\% \text { predicted FVC (com- } \\
\text { posite score) ( } 53 \text { weeks) }\end{array}$ & 1 & & Mean Difference (Fixed, 95\% Cl) & $\begin{array}{l}\text { Totals not select- } \\
\text { ed }\end{array}$ \\
\hline $\begin{array}{l}4.1 \text { Idursulfase } 0.5 \mathrm{mg} / \mathrm{kg} \text { week- } \\
\text { ly }\end{array}$ & 1 & & Mean Difference (Fixed, 95\% Cl) & $0.0[0.0,0.0]$ \\
\hline 4.2 Idursulfase $0.5 \mathrm{mg} / \mathrm{kg}$ EOW & 1 & & Mean Difference (Fixed, 95\% Cl) & $0.0[0.0,0.0]$ \\
\hline 5 Liver volume (\%) (53 weeks) & 1 & & Mean Difference (IV, Fixed, 95\% CI) & $\begin{array}{l}\text { Totals not select- } \\
\text { ed }\end{array}$ \\
\hline $\begin{array}{l}5.1 \text { Idursulfase } 0.5 \mathrm{mg} / \mathrm{kg} \text { week- } \\
\text { ly }\end{array}$ & 1 & & Mean Difference (IV, Fixed, 95\% CI) & $0.0[0.0,0.0]$ \\
\hline 5.2 Idursulfase $0.5 \mathrm{mg} / \mathrm{kg}$ EOW & 1 & & Mean Difference (IV, Fixed, 95\% CI) & $0.0[0.0,0.0]$ \\
\hline 6 Spleen volume (\%) (53 weeks) & 1 & & Mean Difference (IV, Fixed, 95\% CI) & $\begin{array}{l}\text { Totals not select- } \\
\text { ed }\end{array}$ \\
\hline $\begin{array}{l}6.1 \text { Idursulfase } 0.5 \mathrm{mg} / \mathrm{kg} \text { week- } \\
\text { ly }\end{array}$ & 1 & & Mean Difference (IV, Fixed, 95\% CI) & $0.0[0.0,0.0]$ \\
\hline 6.2 Idursulfase $0.5 \mathrm{mg} / \mathrm{kg}$ EOW & 1 & & Mean Difference (IV, Fixed, 95\% CI) & $0.0[0.0,0.0]$ \\
\hline $\begin{array}{l}7 \text { Urine GAG } \mu \mathrm{g} / \mathrm{mg} \text { creatinine } \\
(\%)(53 \text { weeks) }\end{array}$ & 1 & & Mean Difference (IV, Fixed, 95\% CI) & $\begin{array}{l}\text { Totals not select- } \\
\text { ed }\end{array}$ \\
\hline
\end{tabular}




\begin{tabular}{|c|c|c|c|c|}
\hline Outcome or subgroup title & No. of studies & $\begin{array}{l}\text { No. of partici- } \\
\text { pants }\end{array}$ & Statistical method & Effect size \\
\hline $\begin{array}{l}7.1 \text { Idursulfase } 0.5 \mathrm{mg} / \mathrm{kg} \text { week- } \\
\text { ly }\end{array}$ & 1 & & Mean Difference (IV, Fixed, 95\% CI) & $0.0[0.0,0.0]$ \\
\hline 7.2 Idursulfase $0.5 \mathrm{mg} / \mathrm{kg}$ EOW & 1 & & Mean Difference (IV, Fixed, 95\% CI) & $0.0[0.0,0.0]$ \\
\hline $\begin{array}{l}8 \text { One or more infusion-related } \\
\text { adverse events }\end{array}$ & 1 & & Risk Ratio (M-H, Fixed, 95\% Cl) & $\begin{array}{l}\text { Totals not select- } \\
\text { ed }\end{array}$ \\
\hline $\begin{array}{l}8.1 \text { Idursulfase } 0.5 \mathrm{mg} / \mathrm{kg} \text { week- } \\
\text { ly }\end{array}$ & 1 & & Risk Ratio (M-H, Fixed, 95\% Cl) & $0.0[0.0,0.0]$ \\
\hline 8.2 Idursulfase $0.5 \mathrm{mg} / \mathrm{kg}$ EOW & 1 & & Risk Ratio (M-H, Fixed, 95\% Cl) & $0.0[0.0,0.0]$ \\
\hline 9 Serious adverse events & 1 & & Risk Ratio (M-H, Fixed, 95\% Cl) & $\begin{array}{l}\text { Totals not select- } \\
\text { ed }\end{array}$ \\
\hline $\begin{array}{l}9.1 \text { Idursulfase } 0.5 \mathrm{mg} / \mathrm{kg} \text { week- } \\
\text { ly }\end{array}$ & 1 & & Risk Ratio (M-H, Fixed, 95\% Cl) & $0.0[0.0,0.0]$ \\
\hline 9.2 Idursulfase $0.5 \mathrm{mg} / \mathrm{kg}$ EOW & 1 & & Risk Ratio (M-H, Fixed, 95\% Cl) & $0.0[0.0,0.0]$ \\
\hline
\end{tabular}

Analysis 1.1. Comparison 1 Idursulfase $0.5 \mathrm{mg} / \mathrm{kg}$ versus placebo, Outcome 1 Six-minute walk test (6MWT) (53 weeks).

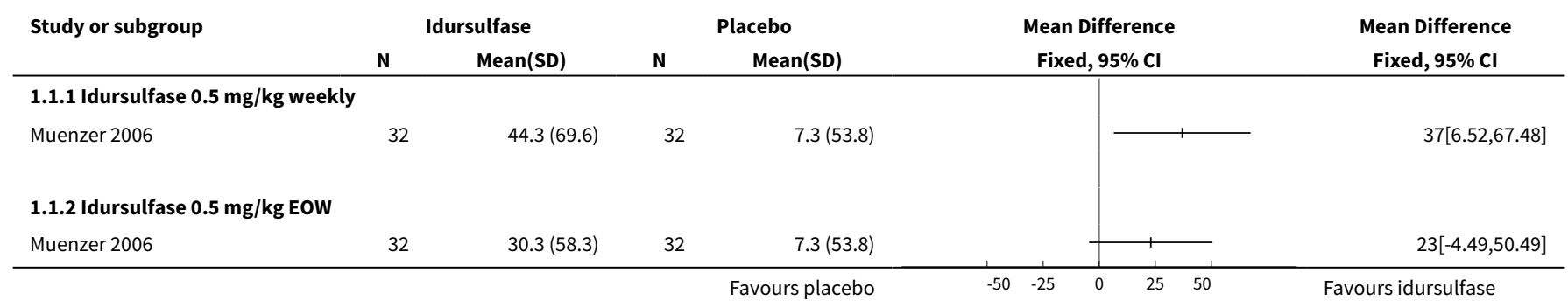

Analysis 1.2. Comparison 1 Idursulfase $0.5 \mathrm{mg} / \mathrm{kg}$ versus placebo, Outcome $2 \%$ predicted FVC (53 weeks).

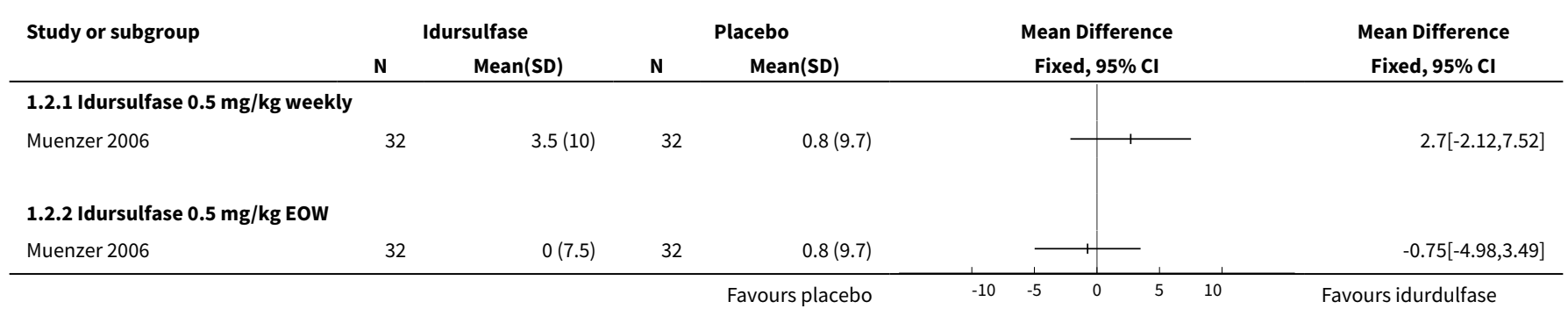


Analysis 1.3. Comparison 1 Idursulfase $0.5 \mathrm{mg} / \mathrm{kg}$ versus placebo, Outcome 3 Absolute FVC (L) (53 weeks).

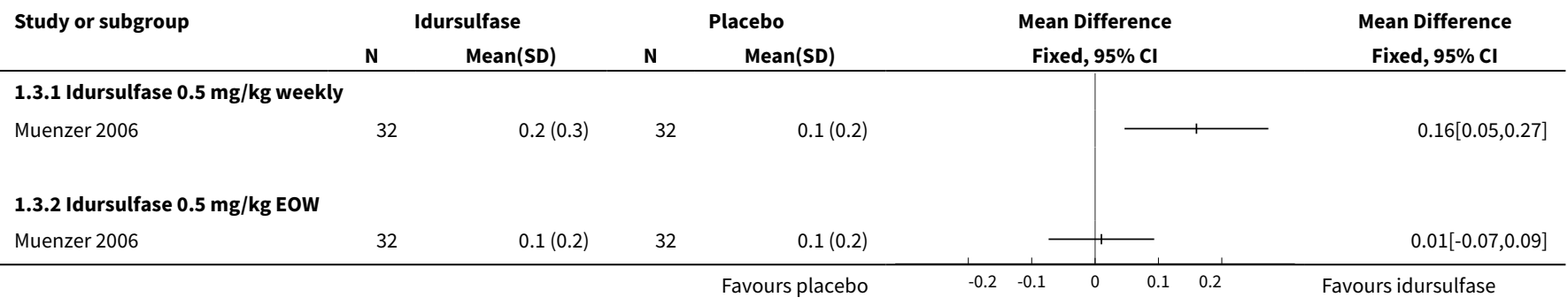

Analysis 1.4. Comparison 1 Idursulfase $0.5 \mathrm{mg} / \mathrm{kg}$ versus placebo, Outcome $46 \mathrm{MWT}+\%$ predicted FVC (composite score) ( 53 weeks).

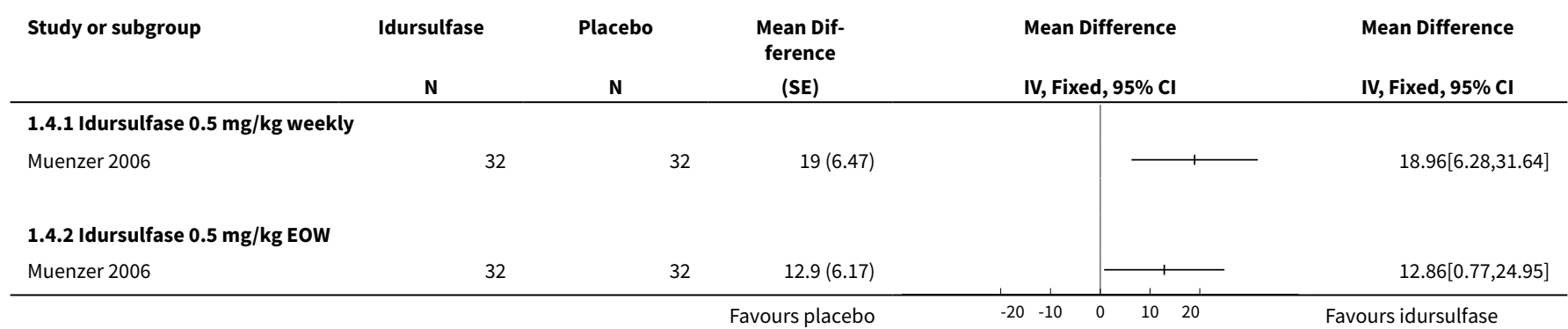

Analysis 1.5. Comparison 1 Idursulfase $0.5 \mathrm{mg} / \mathrm{kg}$ versus placebo, Outcome 5 Liver volume (\%) (53 weeks).

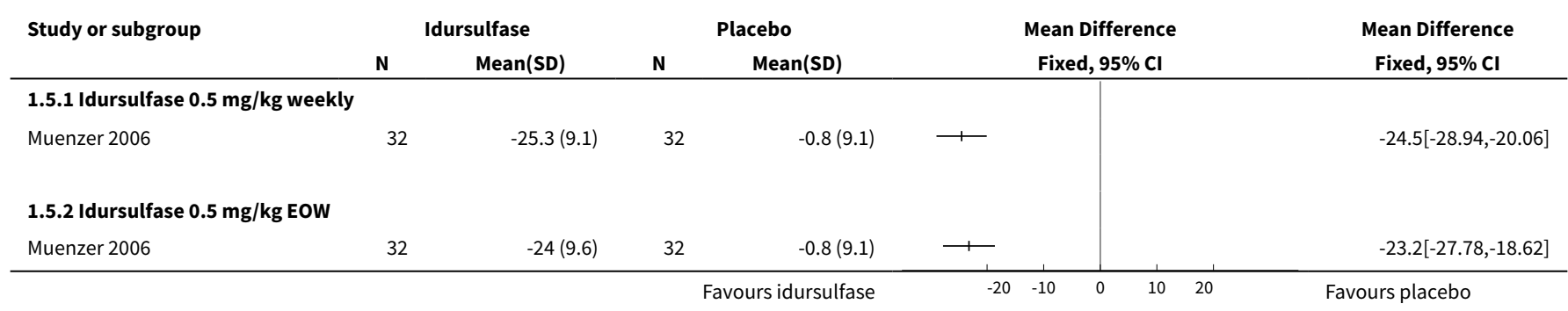

Analysis 1.6. Comparison 1 Idursulfase $0.5 \mathrm{mg} / \mathrm{kg}$ versus placebo, Outcome 6 Spleen volume (\%) (53 weeks).

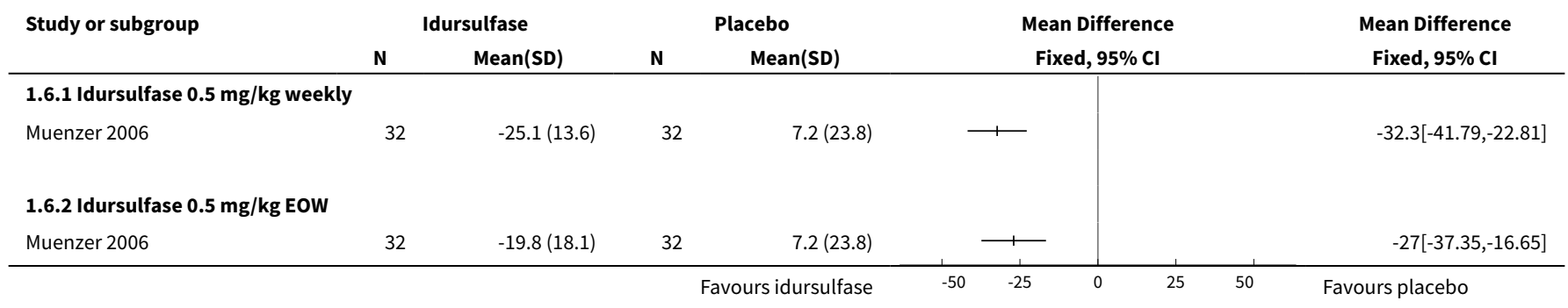


Analysis 1.7. Comparison 1 Idursulfase $0.5 \mathrm{mg} / \mathrm{kg}$ versus placebo, Outcome 7 Urine GAG $\mu \mathrm{g} / \mathrm{mg}$ creatinine (\%)(53 weeks).

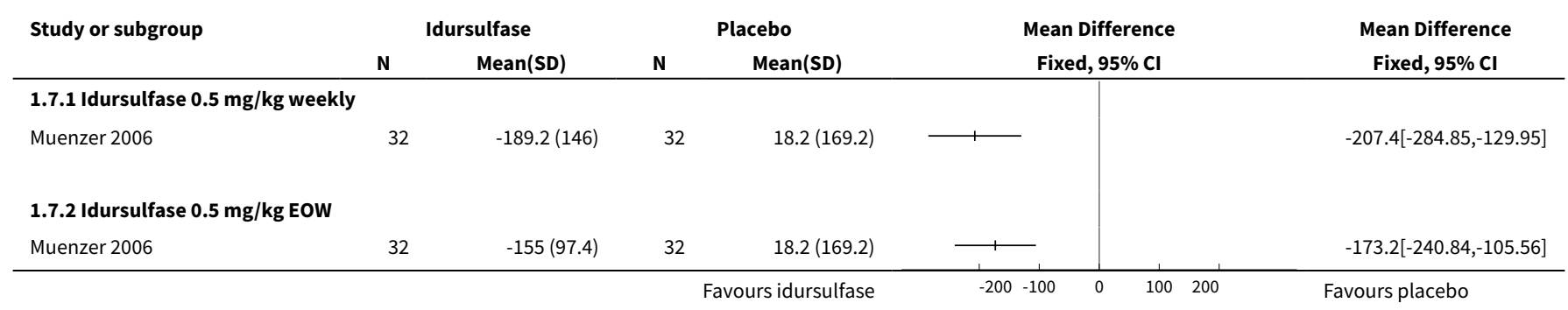

Analysis 1.8. Comparison 1 Idursulfase $0.5 \mathrm{mg} / \mathrm{kg}$ versus placebo, Outcome 8 One or more infusion-related adverse events.

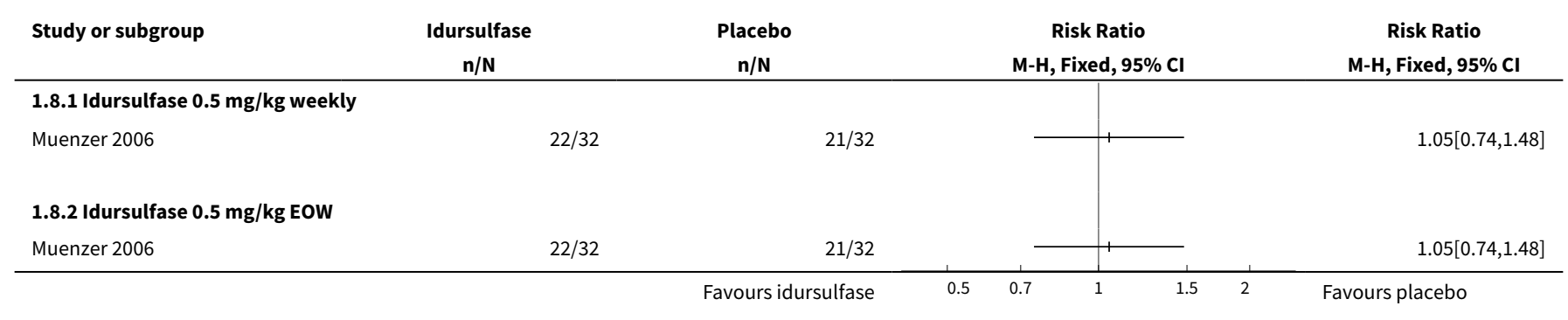

Analysis 1.9. Comparison 1 Idursulfase $0.5 \mathrm{mg} / \mathrm{kg}$ versus placebo, Outcome 9 Serious adverse events.

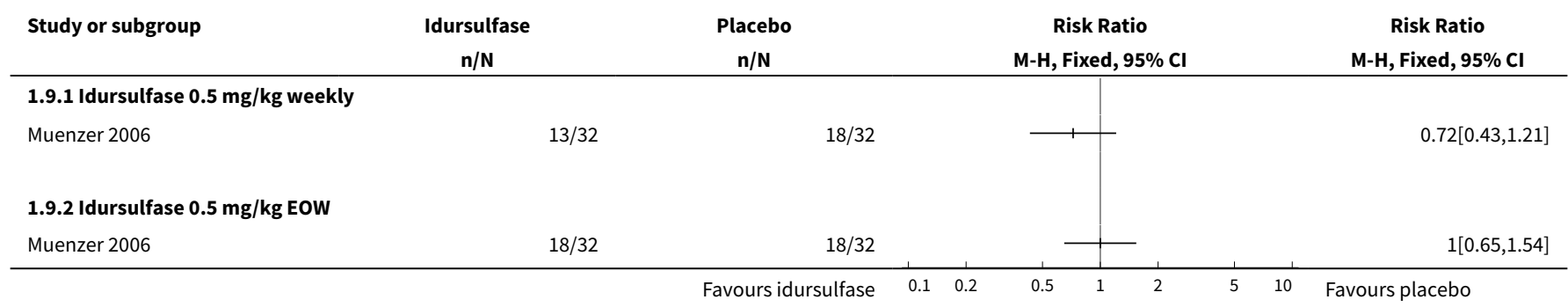

\section{APPENDICES}

\section{Appendix 1. Search strategy - Medline via PubMed}

\#1 Mucopolysaccharidosis II [mh]

\#2 Mucopolysaccharidosis Ils

\#3 Mucopolysaccharidoses Ils

\#4 Hunter Syndrome Gargoylism

\#5 Hunter Syndrome Gargoylisms

\#6 Hunter's Syndrome 
\#7 Hunters Syndrome

\#8 Hunter Syndrome

\#9 MPSII

\#10 MPS II

\#11 Mucopolysaccharidosis 2

\#12 Mucopolysaccharidoses 2

\#13 Mucopolissacaridose II

\#14 Mucopolissacaridosis II

\#15 \#1 OR \#2 OR \#3 OR \#4 OR \#5 OR \#6 OR \#7 OR \#8 OR \#9 OR \#10 OR \#11 OR \#12 OR \#13 OR \#14

\#16 Iduronate Sulfatase [Mh]

\#17 Sulfoiduronate Sulfatase

\#18 Iduronatesulfate Sulfohydrolase

\#19 Hunter Corrective Factor

\#20 Iduronate Sulfate Sulfatase

\#21 Iduronato Sulfatasa

\#22 Iduronato Sulfatase

\#23 \#16 OR \#17 OR \#18 OR \#19 OR \#20 OR \#21 OR \#22

\# 24 randomized controlled trial [pt]

\# 25 controlled clinical trial [pt]

\#26 randomized [tiab]

\#27 placebo [tiab]

\#28 drug therapy [sh]

\#29 randomly [tiab]

\#30 trial [tiab]

\#31 groups [tiab]

\#32 \#24 OR \#25 OR \#26 OR \#27 OR \#28 OR \#29 OR \#29 OR \#30 OR \#31

\#33\#15 AND \#23 AND \#32

\section{Appendix 2. Search strategy - LILACS via Bireme}

\#1 Mucopolysaccharidosis II [mh]

\#2 Mucopolysaccharidosis IIs

\#3 Mucopolysaccharidoses Ils

\#4 Hunter Syndrome Gargoylism

\#5 Hunter Syndrome Gargoylisms

\#6 Hunter's Syndrome

\#7 Hunters Syndrome

Enzyme replacement therapy with idursulfase for mucopolysaccharidosis type II (Hunter syndrome) (Review) 
\#8 Hunter Syndrome

\#9 MPSII

\#10 MPS II

\#11 Mucopolysaccharidosis 2

\#12 Mucopolysaccharidoses 2

\#13 Mucopolissacaridose II

\#14 Mucopolissacaridosis II

\#15 \#1 OR \#2 OR \#3 OR \#4 OR \#5 OR \#6 OR \#7 OR \#8 OR \#9 OR \#10 OR \#11 OR \#12 OR \#13 OR \#14

\#16 Iduronate Sulfatase [Mh]

\#17 Sulfoiduronate Sulfatase

\#18 Iduronatesulfate Sulfohydrolase

\#19 Hunter Corrective Factor

\#20 Iduronate Sulfate Sulfatase

\#21 Iduronato Sulfatasa

\#22 Iduronato Sulfatase

\#23 \#16 OR \#17 OR \#18 OR \#19 OR \#20 OR \#21 OR \#22

\#24 ((Pt RANDOMIZED CONTROLLED TRIAL OR Pt CONTROLLED CLINICAL TRIAL OR Mh RANDOMIZED CONTROLLED TRIALS OR Mh RANDOM ALLOCATION OR Mh DOUBLE-BLIND METHOD OR Mh SINGLE-BLIND METHOD OR Pt MULTICENTER STUDY) OR ((tw ensaio or tw ensayo or tw trial) and (tw azar or tw acaso or tw placebo or tw control\$ or tw aleat\$ or tw random\$ or (tw duplo and tw cego) or (tw doble and tw ciego) or (tw double and tw blind)) and tw clinic\$)) AND NOT ((CT ANIMALS OR MH ANIMALS OR CT RABBITS OR CT MICE OR MH RATS OR MH PRIMATES OR MH DOGS OR MH RABBITS OR MH SWINE) AND NOT (CT HUMAN AND CT ANIMALS)) [Palavras]

\section{\#25 \#15 AND \#23 AND \#24}

\section{Appendix 3. Search strategy - EMBASE via OVID}

\#1 Mucopolysaccharidosis II [mh]

\#2 Mucopolysaccharidosis Ils

\#3 Mucopolysaccharidoses Ils

\#4 Hunter Syndrome Gargoylism

\#5 Hunter Syndrome Gargoylisms

\#6 Hunter's Syndrome

\#7 Hunters Syndrome

\#8 Hunter Syndrome

\#9 MPSII

\#10 MPS I

\#11 Mucopolysaccharidosis 2

\#12 Mucopolysaccharidoses 2

\#13 Mucopolissacaridose II

\#14 Mucopolissacaridosis II

Enzyme replacement therapy with idursulfase for mucopolysaccharidosis type II (Hunter syndrome) (Review)

Copyright $\odot 2016$ The Cochrane Collaboration. Published by John Wiley \& Sons, Ltd. 
\#15 \#1 OR \#2 OR \#3 OR \#4 OR \#5 OR \#6 OR \#7 OR \#8 OR \#9 OR \#10 OR \#11 OR \#12 OR \#13 OR \#14

\#16 Iduronate Sulfatase [Mh]

\#17 Sulfoiduronate Sulfatase

\#18 Iduronatesulfate Sulfohydrolase

\#19 Hunter Corrective Factor

\#20 Iduronate Sulfate Sulfatase

\#21 Iduronato Sulfatasa

\#22 Iduronato Sulfatase

\#23 \#16 OR \#17 OR \#18 OR \#19 OR \#20 OR \#21 OR \#22

\#24 Controlled study/

\#25 Randomization/

\#26 Double blind procedure/

\#27 Single blind procedure/

\#28 Clinical trial/

\#29 (clinical adj5 trial\$).ti,ab,hw.

\#30 ((doubl\$ or singl\$ or tripl\$ or trebl\$) adj5 (blind\$ or mask\$)).ti,ab,hw.

\#31Placebo/

\#32 Placebo\$.ti,ab,hw.

\#33 Random\$.ti,ab,hw.

\#34 Methodology.sh.

\#35 latin square.ti,ab,hw.

\#36 crossover.ti,ab,hw.

\# 37 cross-over.ti,ab,hw.

\#38 Crossover Procedure/

\#39 Drug comparison/

\#40 Comparative study/

\#41 (comparative adj5 trial\$).ti,ab,hw.

\#42 (control\$ or prospectiv\$ or volunteer\$).ti,ab,hw.

\#43 exp "Evaluation and Follow Up"/

\#44 Prospective study/

\#45 or/24-44

\#46 animal/not (human/ and animal/)

\#47 45 not 46

\#48 \#15 OR \#23 OR \#47 
WHAT'S NEW

\begin{tabular}{lll}
\hline Date & Event & Description \\
\hline 3 February 2016 & $\begin{array}{l}\text { New citation required but conclusions } \\
\text { have not changed }\end{array}$ & $\begin{array}{l}\text { Minor changes have been made throughout the review; the con- } \\
\text { clusions remain as per the original publication. }\end{array}$ \\
\hline 3 February 2016 & New search has been performed & $\begin{array}{l}\text { A search of the Cochrane Cystic Fibrosis and Genetic Disorders } \\
\text { Group's Inborn Errors of Metabolism Trials Register identified 36 } \\
\text { references. Searches of Embase, PubMed and LILACS identified a } \\
\text { further three references. }\end{array}$ \\
& $\begin{array}{l}\text { Two references have been added to 'Excluded studies' (Muenzer } \\
\text { 2016; Sohn 2015) and one to 'Ongoing studies' (NCT02055118). } \\
\text { An additional reference has been added to one previously ex- } \\
\text { cluded study (Sohn 2013). }\end{array}$ \\
\hline
\end{tabular}

\section{HISTORY}

Protocol first published: Issue 1, 2010

Review first published: Issue 11, 2011

\begin{tabular}{lll}
\hline Date & Event & Description \\
\hline 6 November 2013 & $\begin{array}{l}\text { New citation required but conclusions } \\
\text { have not changed }\end{array}$ & Minor changes have been made throughout the review. \\
\hline 6 November 2013 & New search has been performed & $\begin{array}{l}\text { We carried out new searches but did not identify any eligible tri- } \\
\text { als for inclusion in the review. }\end{array}$ \\
\hline
\end{tabular}

\section{CONTRIBUTIONS OF AUTHORS}

Edina Mariko Koga da Silva (EMKS) was responsible for the conception of this review.

EMKS and Regis Bruni Andrioli (RBA) were responsible for developing the search strategy and undertaking searches.

EMKS and Laercio Antonio da Silva (LAS) were responsible for screening search results, organising retrieval of papers, screening retrieved papers against the inclusion criteria, appraising quality of papers and extracting data.

EMKS was responsible for data management for the review and entering data into RevMan. EMKS, LAS and Maria Wany Louzada Strufaldi (MWLS) analysed and interpreted the data. EMKS wrote the results. EMKS, LAS and RBA provided a methodological perspective; and MWLS provided a clinical perspective.

\section{DECLARATIONS OF INTEREST}

None known.

\section{SOURCES OF SUPPORT}

\section{Internal sources}

- No sources of support supplied 


\section{External sources}

- National Institute for Health Research, UK.

This systematic review was supported by the National Institute for Health Research, via Cochrane Infrastructure funding to the Cochrane Cystic Fibrosis and Genetic Disorders Group.

\section{DIFFERENCES BETWEEN PROTOCOL ANDREVIEW}

During the completion of the systematic review we received valuable advice from experts on the definition of the outcomes. It was therefore decided for improve the review and to change the primary outcomes to $z$ score of height and weight and six-minutes walk test (6MWT). For further information, please refer to Types of outcome measures.

Within the Results section of the review the final secondary outcome listed was not pre-defined, although this is a composite score of two pre-defined outcomes. This was regarded as being of clinical interest and appropriate to be included within the review.

\section{N DEX TERMS}

\section{Medical Subject Headings (MeSH)}

Drug Administration Schedule; Enzyme Replacement Therapy [ ${ }^{\star}$ methods]; Iduronate Sulfatase [ ${ }^{\star}$ administration \& dosage]; Mucopolysaccharidosis II [ ${ }^{\star}$ drug therapy]; Randomized Controlled Trials as Topic; Rare Diseases [*drug therapy] [enzymology]

\section{MeSH check words}

Humans; Male 